Prepared in cooperation with the Bureau of Reclamation

\title{
Survival, Movement, and Health of Hatchery-Raised Juvenile Lost River Suckers within a Mesocosm in Upper Klamath Lake, Oregon
}

Open-File Report 2016-1012 



\section{Survival, Movement, and Health of Hatchery-Raised Juvenile Lost River Suckers within a Mesocosm in Upper Klamath Lake, Oregon}

By Danielle M. Hereford, Summer M. Burdick, Diane G. Elliott, Amari Dolan-Caret, Carla M. Conway, and Alta C. Harris

Prepared in cooperation with the Bureau of Reclamation

Open-File Report 2016-1012

U.S. Department of the Interior

U.S. Geological Survey 


\section{U.S. Department of the Interior \\ SALLY JEWELL, Secretary}

\section{U.S. Geological Survey \\ Suzette M. Kimball, Director}

U.S. Geological Survey, Reston, Virginia: 2016

For more information on the USGS—-the Federal source for science about the Earth, its natural and living resources, natural hazards, and the environment-visit http://www.usgs.gov/ or call 1-888-ASK-USGS (1-888-275-8747).

For an overview of USGS information products, including maps, imagery, and publications, visit http://www.usgs.gov/pubprod/.

Any use of trade, firm, or product names is for descriptive purposes only and does not imply endorsement by the U.S. Government.

Although this information product, for the most part, is in the public domain, it also may contain copyrighted materials as noted in the text. Permission to reproduce copyrighted items must be secured from the copyright owner.

Suggested citation:

Hereford, D.M., Burdick, S.M., Elliott, D.G., Dolan-Caret, Amari, Conway, C.M., and Harris, A.C., 2016, Survival, movement, and health of hatchery-raised juvenile Lost River suckers within a mesocosm in Upper Klamath Lake, Oregon: U.S. Geological Survey Open-File Report 2016-1012, 48 p., http://dx.doi.org/10.3133/ofr20161012.

ISSN 2331-1258 (online) 


\section{Contents}

Abstract

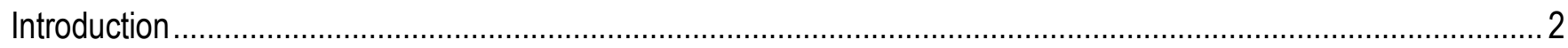

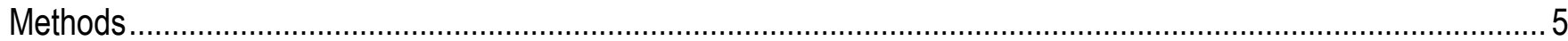

Mesocosm Design, Fish Introduction, and Sampling the Mesocosm …………………...............................

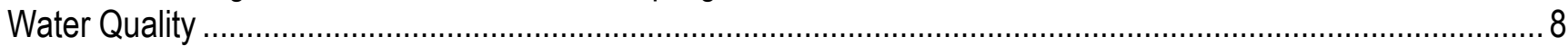

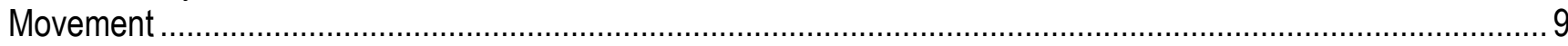

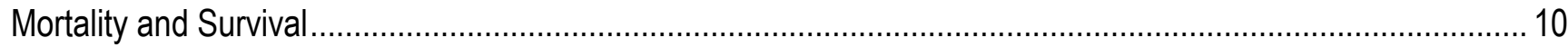

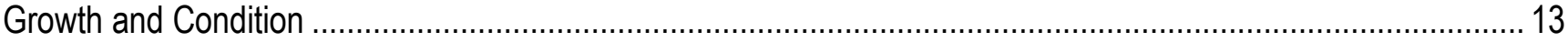

Sucker Health and Determination of Cause of Death................................................................................. 13

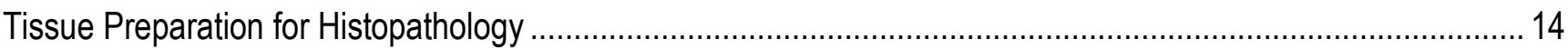

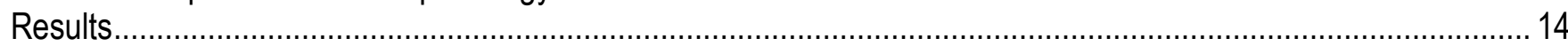

Seasonal Variation in Depth, Temperature, Dissolved Oxygen, and pH ...................................................... 14

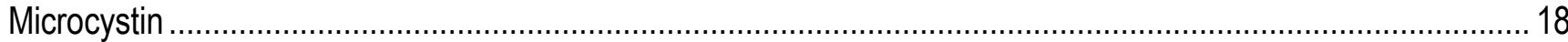

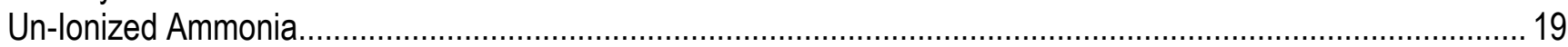

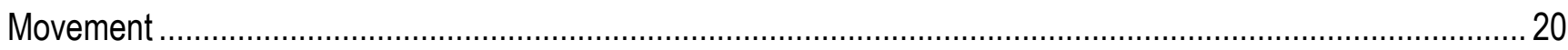

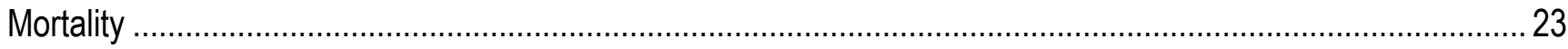

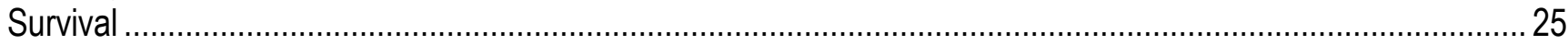

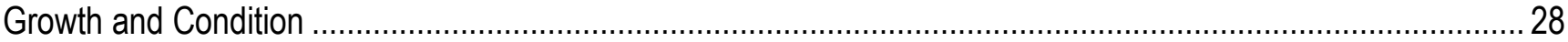

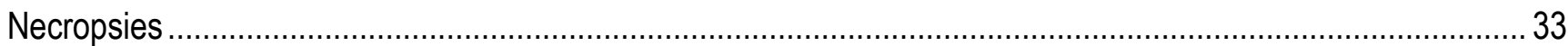

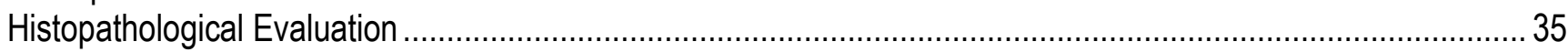

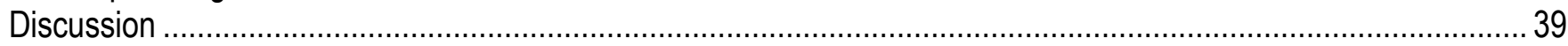

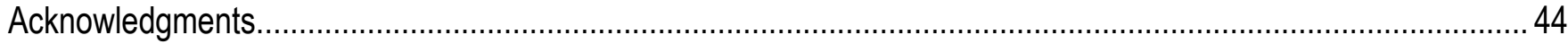

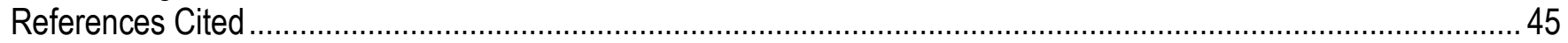

\section{Figures}

Figure 1. Map depicting location of the mesocosm in Upper Klamath Lake, Oregon .......................................... 6

Figure 2. Water depth and depth of water quality readings in the mesocosm in Upper Klamath Lake, Oregon..... 15

Figure 3. Mean (black circle), minimum (bottom bar), and maximum (top bar) daily water temperatures in the mesocosm in Upper Klamath Lake, Oregon, July 9-September 15, $2014 .$.

Figure 4. Mean (black circle), minimum (bottom bar), and maximum (top bar) daily dissolved-oxygen

concentrations in the mesocosm in Upper Klamath Lake, Oregon, July 9-September 15, 2014

Figure 5. Mean (black circle), minimum (bottom bar), and maximum (top bar) daily pH in the mesocosm in Upper Klamath Lake, Oregon, July 9-September 15, 2014.

Figure 6. Concentrated particulate (a) and dissolved fraction (b) microcystin concentrations approximately 100 meters from the mesocosm in Upper Klamath Lake, Oregon, July 16-September 15, 2014.

Figure 7. Un-ionized ammonia concentrations approximately 100 meters from the mesocosm in Upper Klamath Lake, Oregon, July 16-September 10, 2014.

Figure 8. Diurnal vertical movement patterns of juvenile Lost River suckers in the mesocosm in Upper Klamath Lake, Oregon, summarized as percent reads per hour among Surface and Benthos antennas during (a) early (July 2-28), (b) middle (July 29-August 21), and (c) late (August 22-September 15) season

Figure 9. Percentage of hourly activity (reads) near benthic and surface antennas of juvenile Lost River suckers and dissolved-oxygen concentration (DO; $\mathrm{mg} / \mathrm{L})$ near surface and near benthos in the mesocosm in Upper Klamath Lake, Oregon, on (a) July 14, 2014, and (b) July 15, 2014 
Figure 10. Total number of natural daily mortalities for age-1 (groups 1-7) and age-2 (groups 8 and 9) juvenile Lost River suckers in the mesocosm in Upper Klamath Lake, Oregon, July 2-September 15, 2014.

Figure 11. Total number of Lost River suckers alive in the mesocosm in Upper Klamath Lake, Oregon, July 2September 15, 2014. Observed reductions in groups are due to natural mortality and scheduled sacrifices

Figure 12. Daily survival estimates and 95-percent confidence intervals for age-1 juvenile Lost River suckers in the mesocosm in Upper Klamath Lake, Oregon, July 2-September 15, 2014

Figure 13. Change in standard length and total number of days in the mesocosm for juvenile Lost River suckers in Upper Klamath Lake, Oregon

Figure 14. Change in weight and total number of days in the mesocosm for juvenile Lost River suckers in Upper Klamath Lake, Oregon .

Figure 15. Change in body condition $\left(K=\left(w t / S L^{3}\right)^{*} 10^{5}\right)$ and total number of days in the mesocosm for juvenile Lost River suckers in Upper Klamath Lake, Oregon

Figure 16. Whole fish triglyceride levels ( $\mathrm{mg} / \mathrm{g}$ of body tissue) of juvenile Lost River suckers sacrificed directly from the research facility, and at 3 (7-28-14), 6 (8-18-14), and 8 (9-2-14) weeks post introduction from group 2, Upper Klamath Lake, Oregon.

Figure 17. Gill lamellae from moribund Lost River suckers sampled from the mesocosm in Upper Klamath Lake

Figure 18. Ichthyobodo sp. parasites (arrows) attached to the gill lamellar epithelium 37

\section{Tables}

Table 1. Group information and size of 395 hatchery-raised Lost River suckers when introduced to the mesocosm in Upper Klamath Lake, Oregon, July 2-September 15, 2014.

Table 2. Fates for 395 hatchery-raised Lost River suckers in the mesocosm in Upper Klamath Lake, Oregon, July 2-September 15, 2014

Table 3. Description of a priori hypotheses tested to describe juvenile Lost River sucker mortality within the mesocosm in Upper Klamath Lake, Oregon

Table 4. Average \pm standard deviation and maximum number of days one or more fish was alive in the mesocosm, and the total number of days available (from date of introduction to September 15) for each group of hatchery-raised Lost River suckers in the mesocosm in Upper Klamath Lake, Oregon, July 2-September 15, 2014.

Table 5. Model selection results for Kaplan Meier models fit to estimate daily survival of age- 1 juvenile Lost River suckers in the mesocosm in Upper Klamath Lake, Oregon, July 2-September 15, 2014

Table 6. Prevalence of parasites, bacterial disease, and other abnormalities for moribund $(n=14)$ and sacrificed, non-moribund $(n=192)$ Lost River suckers in the mesocosm in Upper Klamath Lake, Oregon

Table 7. Condition of tissues from necropsies performed in the field immediately following sacrifice for moribund $(n=14)$ and sacrificed, non-moribund $(n=78)$ Lost River suckers in the mesocosm in Upper Klamath Lake, Oregon.

Table 8. Prevalence and percent occurrence of inflammation, necrosis, other histopathological changes, and parasites in gill tissue of Lost River suckers from the mesocosm in Upper Klamath Lake, Oregon 38

Table 9. Prevalence and percent occurrence of inflammation and necrosis in tissues of Lost River suckers from the mesocosm in Upper Klamath Lake, Oregon 38

Table 10. Hepatocellular glycogen distribution evaluated by periodic acid-Schiff (PAS) and PAS-diastase staining in Lost River suckers from the mesocosm in Upper Klamath Lake, Oregon. 


\section{Conversion Factors}

International System of Units to Inch/Pound

\begin{tabular}{|c|c|c|}
\hline Multiply & By & To obtain \\
\hline \multicolumn{3}{|c|}{ Length } \\
\hline nanometer (nm) & $3.93701 \times 10^{-8}$ & inch (in.) \\
\hline micrometer $(\mu \mathrm{m})$ & 0.000039 & inch (in.) \\
\hline centimeter $(\mathrm{cm})$ & 0.3937 & inch (in.) \\
\hline millimeter (mm) & 0.03937 & inch (in.) \\
\hline meter $(\mathrm{m})$ & 3.281 & foot $(\mathrm{ft})$ \\
\hline kilometer $(\mathrm{km})$ & 0.6214 & mile (mi) \\
\hline \multicolumn{3}{|c|}{ Area } \\
\hline square centimeter $\left(\mathrm{cm}^{2}\right)$ & 0.001076 & square foot $\left(\mathrm{ft}^{2}\right)$ \\
\hline square centimeter $\left(\mathrm{cm}^{2}\right)$ & 0.1550 & square inch $\left(\mathrm{ft}^{2}\right)$ \\
\hline \multicolumn{3}{|c|}{ Volume } \\
\hline microliter $(\mu \mathrm{L})$ & $3.381 \times 10^{-5}$ & ounce, fluid (fl. oz) \\
\hline milliliter (mL) & 0.0338 & Ounce, fluid (fl. oz) \\
\hline liter $(\mathrm{L})$ & 33.81402 & ounce, fluid (fl. oz) \\
\hline liter $(\mathrm{L})$ & 61.02 & cubic inch $\left(\right.$ in $\left.^{3}\right)$ \\
\hline \multicolumn{3}{|c|}{ Mass } \\
\hline $\operatorname{gram}(\mathrm{g})$ & 0.03527 & ounce, avoirdupois (oz) \\
\hline kilogram (kg) & 2.205 & pound avoirdupois (lb) \\
\hline milligram & $3.5274 \times 10^{-5}$ & ounce, avoirdupois (oz) \\
\hline microgram & $3.5274 \times 10^{-8}$ & ounce, avoirdupois (oz) \\
\hline nanogram (ng) & $3.53 \times 10^{-11}$ & ounce, avoirdupois (oz) \\
\hline
\end{tabular}

Temperature in degrees Celsius $\left({ }^{\circ} \mathrm{C}\right)$ may be converted to degrees Fahrenheit $\left({ }^{\circ} \mathrm{F}\right)$ as:

$$
{ }^{\circ} \mathrm{F}=\left(1.8 \times{ }^{\circ} \mathrm{C}\right)+32 .
$$




\section{Datum}

Horizontal coordinate information is referenced to the North American Datum of 1983 (NAD 83).

\section{Supplemental Information}

Concentrations of chemical constituents in water are given in either milligrams per liter $(\mathrm{mg} / \mathrm{L})$ or micrograms per liter $(\mu \mathrm{g} / \mathrm{L})$.

\begin{tabular}{|c|c|}
\hline $\mathrm{AlC}_{\mathrm{c}}$ & Akaike's information criterion for small sample size \\
\hline CV & coefficient of variation \\
\hline $\mathrm{DI}$ & deionized water \\
\hline DO & dissolved-oxygen \\
\hline ELISA & enzyme-linked immunosorbent assay \\
\hline K & body condition $\mathrm{K}=\left(\mathrm{wt} / \mathrm{SL} \mathrm{L}^{3}\right) \times 10^{5}$ \\
\hline MS-222 & tricaine mesylate \\
\hline $\mathrm{NH}_{3}$ & un-ionized ammonia \\
\hline PAS & periodic acid-Schiff \\
\hline PIT & passive integrated transponder \\
\hline PVC & poly(vinyl chloride) \\
\hline SD & standard deviation \\
\hline SL & standard length \\
\hline USGS & U.S. Geological Survey \\
\hline wt & weight in grams \\
\hline $\mathrm{xg}$ & gravitational force \\
\hline$p$ & survival \\
\hline
\end{tabular}




\title{
Survival, Movement, and Health of Hatchery-Raised Juvenile Lost River Suckers within a Mesocosm in Upper Klamath Lake, Oregon
}

By Danielle M. Hereford, Summer M. Burdick, Diane G. Elliott, Amari Dolan-Caret, Carla M. Conway, and Alta C. Harris

\begin{abstract}
The recovery of endangered Lost River suckers (Deltistes luxatus) in Upper Klamath Lake is limited by poor juvenile survival and failure to recruit into the adult population. Poor water quality, degradation of rearing habitat, and toxic levels of microcystin are hypothesized to contribute to low juvenile survival. Studies of wild juvenile suckers are limited in that capture rates are low and compromised individuals are rarely captured in passive nets. The goal of this study was to assess the use of a mesocosm for learning about juvenile survival, movement, and health. Hatchery-raised juvenile Lost River suckers were PIT (passive integrated transponder) tagged and monitored by three vertically stratified antennas. Fish locations within the mesocosm were recorded at least every 30 minutes and were assessed in relation to vertically stratified water-quality conditions. Vertical movement patterns were analyzed to identify the timing of mortality for each fish. Most mortality occurred from July 28 to August 16, 2014. Juvenile suckers spent daylight hours near the benthos and moved throughout the entire water column during dark hours. Diel movements were not in response to dissolved-oxygen concentrations, temperature, or $\mathrm{pH}$. Furthermore, low dissolved-oxygen concentrations, high temperatures, high $\mathrm{pH}$, high un-ionized ammonia, or high microcystin levels did not directly cause mortality, although indirect effects may have occurred. However, water-quality conditions known to be lethal to juvenile Lost River suckers did not occur during the study period. Histological assessment revealed severe gill hyperplasia and Ichthyobodo sp. infestations in most moribund fish. For these fish, Ichthyobodo sp. was likely the cause of mortality, although it is unclear if this parasite originated in the rearing facility because fish were not screened for this parasite prior to introduction. This study has demonstrated that we can effectively use a mesocosm equipped with antennas to learn about the timing of mortality, movement, and health of PIT-tagged hatchery-raised juvenile Lost River suckers.
\end{abstract}




\section{Introduction}

Lost River sucker (Deltistes luxatus) was listed as endangered following substantial declines in abundance that occurred over the last century. Historically, these long-lived large-bodied catostomids thrived throughout the Upper Klamath Basin in southern Oregon and northern California (National Research Council, 2004). Suckers were an important fish for Native Americans, especially in Upper Klamath Lake, the largest lentic sucker ecosystem in the basin (Markle and Cooperman, 2002). Population declines were first observed in the mid-1960s when annual recreational harvests were approximately 10,000 fish; a reduction from historical subsistence harvests (Markle and Cooperman, 2002). The extent of the sucker decline was realized 2 decades later when a fish die-off in Upper Klamath Lake revealed a limited age class distribution, which suggested that substantial recruitment into the adult population had not occurred in over a decade (Markle and Cooperman, 2002; National Research Council, 2004). The sucker fishery was closed in 1987, and Lost River suckers were listed as endangered in 1988 (U.S. Fish and Wildlife Service, 1988). Poor water quality, reduced habitat, high nutrient levels, increased abundance of non-native fish species, and changes in algal bloom dynamics are possible causes of population decline.

For the largest remaining population of Lost River suckers, recruitment appears to be limited by survival during the juvenile life stage. Lost River suckers are more abundant in Upper Klamath Lake than anywhere else in their range. Recruitment has been closely monitored by trapping, tagging, and tracking the survival of more than 40,000 adult suckers in spawning aggregates from 1999 to 2012 (Hewitt and others, 2014). Fork length data and recruitment estimates from mark-recapture data suggest recruitment into the adult population has been limited during this time (Hewitt and others, 2014). Adult suckers are becoming larger, and previously unseen fish are not smaller, younger recruits.

Spawning aggregations of adult Lost River suckers are found in shoreline springs and tributaries to Upper Klamath Lake in March, April, and May (Hewitt and others, 2014). Larvae emerge from the gravels, and those spawned in the river passively drift downstream to Upper Klamath Lake between mid-April and late-May (Ellsworth and Martin, 2012; Hewitt and others, 2014). Age-0 suckers are captured throughout the lake and are relatively abundant until mid- to late September when catches decline (Ellsworth and others, 2009; Bottcher and Burdick, 2010; Burdick and Hewitt, 2012). Very few age-1 or age-2 suckers are captured throughout Upper Klamath Lake in April and June, after which captures of these age classes are extremely rare (Bottcher and Burdick, 2010; Burdick and VanderKooi, 2010; Burdick and Hewitt, 2012). Despite extensive sampling throughout Upper Klamath Lake, abrupt declines in age- 0 catches and the scarcity of all other juvenile captures indicate near complete group failure during the juvenile life stage (Bottcher and Burdick, 2010; Burdick and VanderKooi, 2010; Burdick and Hewitt, 2012). 
Many physical and biological changes have occurred in Upper Klamath Basin during the first half of the 20th century that coincide with the decrease in sucker abundance and these alterations may provide clues to the cause of the species' decline. Phosphorus levels are naturally high due to the volcanic geology of the region but are augmented by run off from historical and current agriculture and timber harvest practices, which has modified Upper Klamath Lake to a hypereutrophic lake (Eilers and others, 2001; Bradbury and others, 2004; National Research Council, 2004). Sediment cores have revealed changes in Upper Klamath Lake water quality over the last 150 years including changes in nutrients and minerals $\left(\mathrm{Pb}, \mathrm{C}, \mathrm{N},{ }^{15} \mathrm{~N}, \mathrm{P}, \mathrm{C}, \mathrm{Ti}\right.$, and $\mathrm{Al}$ ), diatoms, cyanobacteria (also called blue-green algae), and green algae (Eilers and others, 2001). Large increases in titanium, aluminum, and sediment accumulation during the 20th century are consistent with increased erosional input caused by historical land-use activities (Eilers and others, 2001). Nutrient concentrations of carbon, nitrogen, and phosphorus also have increased over the last 150 years, and diatom communities have exhibited modest changes in species composition (Eilers and others, 2001). One previously abundant taxa of green alga Pediastrum sharply declined while a cyanobacteria Aphanizomenon flos-aquae previously not present in Upper Klamath Lake, has become very abundant (Eilers and others, 2001). Sediment cores indicate that, in more recent history (30-40 years), major changes in water quality and phytoplankton assemblage have occurred (Eilers and others, 2001).

Current water-quality conditions in Upper Klamath Lake are driven by large bloom and crash cycles of $A$. flos-aquae, a cyanobacterium capable of fixing its own nitrogen (National Research Council, 2004; Eldridge and others, 2013). Throughout the summer, A. flos-aquae increases in abundance, relatively uninhibited by nutrient limitations. A massive $A$. flos-aquae die-off typically occurs following extended periods of calm weather conditions (National Research Council, 2004). Low dissolved-oxygen (DO) concentrations, high temperatures, high $\mathrm{pH}$, and elevated un-ionized ammonia concentrations are potentially stressful water-quality conditions that coincide with large $A$. flos-aquae blooms and subsequent die-offs (Kann and Smith, 1999; Eldridge and others, 2013). The confounded effect of some or all of these water-quality parameters may contribute to juvenile sucker mortality.

Other species of cyanobacteria are present in Upper Klamath Lake to a lesser degree, including Microcystis aeruginosa, a species capable of producing the toxic secondary metabolite microcystin (Eldridge and others, 2013). M. aeruginosa is usually less than 1 percent of the total phytoplankton biomass but concentrations increase after the $A$. flos-aquae die-off and nitrogen becomes available through decomposition (Eldridge and others, 2013). Suckers in Upper Klamath Lake could be exposed to microcystin by swimming in contaminated water or by consuming the toxinogenic cells. Microcystin toxins target the liver but laboratory and field studies of rainbow trout (Oncorhynchus mykiss), whitefish (Coregonus lavaretus), zebrafish (Danio rerio), and other fish species have shown that microcystins can also affect other organs, growth, behavior, osmoregulation, and heart rate at different life stages (Malbrouck and Kestemont, 2006). Toxins from M. aeruginosa have been linked to tumor promotion and various diseases in wildlife and domestic animals (Carmichael, 1994; Falconer, 1999). For juvenile and adult life stages of fish, immersion in microcystin-contaminated water is less harmful than consuming affected cells (Malbrouck and Kestemont, 2006). Lost River suckers are benthic feeders and could be consuming $M$. aeruginosa from the substrate (Eldridge and others, 2013). It is unclear if microcystin toxins are contributing to high juvenile mortality in Upper Klamath Lake as preliminary laboratory feeding trials have produced inconclusive results (Barbara A. Martin, U.S. Geological Survey, oral commun., 2015). 
Juvenile sucker survival is difficult to estimate and factors affecting survival are difficult to study in this large ecosystem. Understanding survival for juveniles in Upper Klamath Lake is especially difficult because captures are low, distribution is patchy, and captures decline rapidly throughout the season. Mark-recapture methods of survival estimation are limited by sample size and re-detection rates. In general, fewer than 250 juveniles large enough [ $\geq 70 \mathrm{~mm}$ standard length (SL)] to tag with a passive integrated transponder (PIT) tags are captured each year, and redetection rates for these juveniles are low. For example, one study that tagged 592 juvenile suckers in Upper Klamath Lake from 2009 to 2012 redetected only 6.7 percent of tags on remote PIT tag antennas and on scans of bird colonies (Burdick, 2013). Additionally, many of the factors affecting juvenile survival and health such as parasites, disease, and poor water quality could be causing the biggest challenge associated with studying survival, low capture rates.

An alternate method to study juvenile health and survival is to introduce juvenile Lost River suckers into a mesocosm within the natural environment. Typically, mesocosms isolate part of a natural ecosystem and allow researchers to control or manipulate some aspects of the study environment (Horne and Goldman, 1994). Individual fish can be closely monitored in mesocosms, and sample sizes are easily manipulated. Many studies have used mesocosms to monitor survival, growth, movement, and understand interspecific relationships (Welker and others, 1994; Williams and others, 2002).

In this study, we used one large mesocosm to monitor the health, daily survival, and hourly movement of hatchery-raised Lost River suckers in Upper Klamath Lake. The specific objectives for this pilot study were to (1) assess our ability to quantify temporal survival for hatchery-reared juvenile Lost River suckers within a mesocosm in Upper Klamath Lake, (2) assess our ability to identify changes in health, growth, and body condition of suckers throughout the summer, (3) assess our ability to study movement patterns in relation to water-quality conditions, and (4) to summarize how survival, health, and movement patterns varied throughout the summer and relative to the water-quality parameters we measured. To estimate survival of age-1 suckers, we monitored daily movement and survival of PITtagged fish with vertically stratified remote sensing antenna arrays in a mesocosm within Upper Klamath Lake. Healthy and moribund individuals were sacrificed to assess general health from July to mid-September 2014. Water-quality parameters were measured near the surface $(30 \mathrm{~cm}$ from the top of the water column) and near the benthos ( $30 \mathrm{~cm}$ from the bottom of the water column) throughout this study to assess how sucker survival and behavior was affected by changes in water quality. Un-ionized ammonia and microcystin concentrations were quantified weekly to monitor seasonal trends in relation to sucker survival, health, and behavior. 


\section{Methods}

\section{Mesocosm Design, Fish Introduction, and Sampling the Mesocosm}

We deployed a $3 \times 3 \times 3$ m net pen (hereinafter "mesocosm") in the Fish Banks area of Upper Klamath Lake (fig. 1). Several springs enter Upper Klamath Lake in this area, so water quality is relatively good. We chose to place the mesocosm at Fish Banks because fish would likely survive at least part of the study duration in this location. The frame of the mesocosm was constructed of $7.62 \mathrm{~cm}$ PVC. A large net made of $0.64 \mathrm{~cm}^{2}$ mesh $(20 \mathrm{~kg})$ nylon was manufactured with corner-to-corner sleeves that held the PVC frame. A buoyant dock 1- to 2-m wide surrounded the mesocosm, kept the mesocosm anchored in one location, and provided researchers easy access to the mesocosm. Bird netting with 2.5

$\mathrm{cm}^{2}$ mesh was hung across the top of the mesocosm to prevent avian predation. Three vertically stacked antennas $(1.2 \times 0.6 \mathrm{~m})$ detected PIT-tagged suckers within the center of the mesocosm. These antennas were placed (1) near the water surface, (2) in the middle of the water column, and (3) on the benthos. Additionally, two smaller $(0.3 \times 0.3 \mathrm{~m})$ antennas were placed in opposite corners on the bottom of the mesocosm to track horizontal benthic movement. To avoid overloading data storage capabilities, once a tag was detected on an antenna, subsequent detections of the same tag on the same antenna were not recorded for 30 minutes. A detection of the same tag on another antenna would restart the clock on all antennas, such that rapid movement was still detected.

Lost River suckers propagated from wild adult Lost River suckers in 2012 and 2013 were raised from eggs at the Coleman National Fish Hatchery (U.S. Fish and Wildlife Service, Anderson, California) and kept as juveniles at the Klamath Tribes Fish Research Facility (Chiloquin, Oregon). We sedated 301 age-1 and 120 age-2 juvenile suckers with tricaine mesylate (MS-222) and tagged all fish with 12-mm, $134.2 \mathrm{kHz}$ PIT tags. Biomark ${ }^{\circledR}$ MK25 implant guns were used to insert preloaded needles into the body cavity between the pectoral fins on the underside of the fish. All tags were injected from the anterior end towards the posterior end to keep the needle and tag away from the heart. All fish were held in two research tanks (one for each age class) to recover from tagging for at least 20 days. Within the first week, 16 (less than 4 percent) fish died from tagging, and 5 fish shed their tags. No additional mortalities occurred post tagging after the first week in the research tanks. Tag failure was rare $(\mathrm{n}=1)$ but, when it occurred, the fish was removed from all analyses due to low detection rates.

Release batches (hereinafter "groups") of juvenile Lost River suckers were introduced to the mesocosm weekly from July 2 to September 2 (table 1). Staggered entry was implemented to test the carrying capacity of the mesocosm and to avoid any unexpected pitfalls associated with introducing all fish at once (for example, early season mortality). All fish were scanned for a PIT tag, measured to SL, and weighed prior to entry. Fish ranged in SL from 90 to $177 \mathrm{~mm}$ and in weight from 7.6 to $72.9 \mathrm{~g}$ (table 1).

Each week, a subset of non-moribund fish $(\mathrm{n}=5-15)$ were removed from the mesocosm and sacrificed to assess changes in health or triglycerides. The mesocosm was sampled by lifting two or three bottom corners onto the dock and dip-netting suckers out of the mesocosm net pen. During weekly sampling, all netted fish were scanned and either returned to the mesocosm or sacrificed (table 2). At the end of the study (September 15), all fish still alive were sacrificed. 


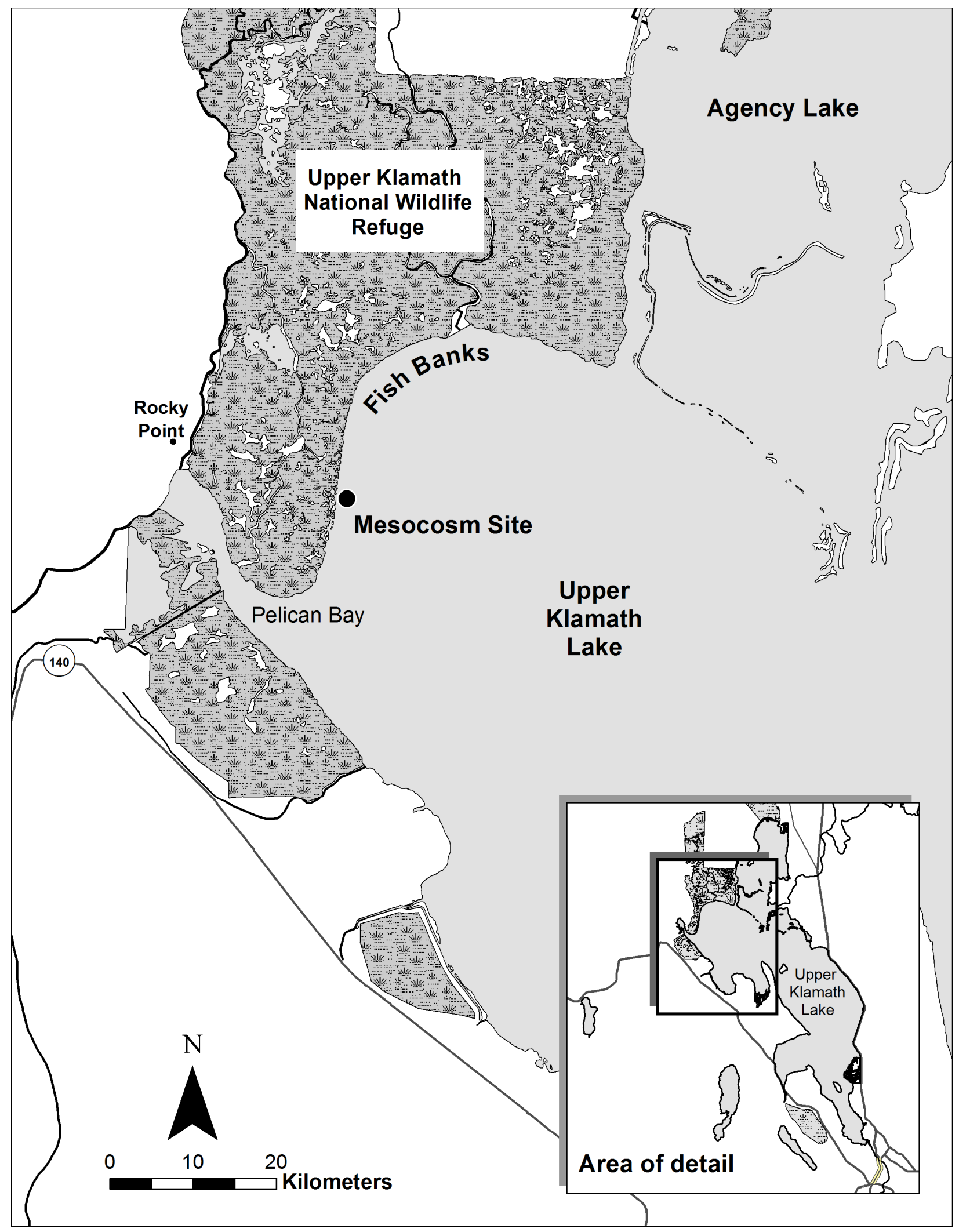

Figure 1. Map depicting location of the mesocosm in Upper Klamath Lake, Oregon. 
Table 1. Group information and size of 395 hatchery-raised Lost River suckers when introduced to the mesocosm in Upper Klamath Lake, Oregon, July 2-September 15, 2014.

[SL, standard length; wt, weight]

\begin{tabular}{l|c|c|c|c|c|c|c|c|c|c|}
\hline & \multicolumn{9}{c|}{ Group } \\
\cline { 2 - 10 } & $\mathbf{1}$ & $\mathbf{2}$ & $\mathbf{3}$ & $\mathbf{4}$ & $\mathbf{5}$ & $\mathbf{6}$ & $\mathbf{7}$ & $\mathbf{8}$ & $\mathbf{9}$ & All \\
\hline & & & & & & & & & \\
Group size & 20 & 45 & 45 & 50 & 54 & 55 & 8 & 55 & 63 \\
Date introduced & $7-02-14$ & $7-07-14$ & $7-14-14$ & $7-21-14$ & $7-28-14$ & $8-04-14$ & $8-11-14$ & $8-25-14$ & $9-02-14$ & 395 \\
Age $^{1}$ & 1 & 1 & 1 & 1 & 1 & 1 & 1 & 2 & 2 & $1-2$ \\
$\mathrm{SL}^{2,3}$ & $97.5 \pm 4.8$ & $100.8 \pm 4.4$ & $100.4 \pm 4.6$ & $100.6 \pm 5.5$ & $102.3 \pm 5.3$ & $104.4 \pm 5.8$ & $104 \pm 5.3$ & $161.3 \pm 7.0$ & $156.1 \pm 7.2$ & $118.6 \pm 26.8$ \\
wt $^{3,4}$ & $13.0 \pm 2.0$ & $13.7 \pm 2.2$ & $13.7 \pm 2.3$ & $14.1 \pm 2.4$ & $14.8 \pm 2.4$ & $15.6 \pm 2.9$ & $15.9 \pm 2.8$ & $51.3 \pm 8.2$ & $49.9 \pm 8.6$ & $25.2 \pm 17.3$ \\
\hline
\end{tabular}

${ }^{1}$ Years.

${ }^{2}$ Standard length, in millimeters.

${ }^{3}$ Average \pm standard deviation.

${ }^{4}$ Weight in grams.

Table 2. Fates for 395 hatchery-raised Lost River suckers in the mesocosm in Upper Klamath Lake, Oregon, July 2-September 15, 2014.

\begin{tabular}{lrrrrrrrrrr}
\hline \multicolumn{1}{c}{ Fate } & \multicolumn{10}{c}{ Group } \\
\cline { 2 - 11 } & $\mathbf{1}$ & $\mathbf{2}$ & \multicolumn{1}{c}{$\mathbf{3}$} & $\mathbf{4}$ & $\mathbf{5}$ & $\mathbf{6}$ & $\mathbf{7}$ & $\mathbf{8}$ & $\mathbf{9}$ & \multicolumn{1}{c}{ All } \\
\hline Found dead $^{1,2}$ & 9 & 17 & 24 & 40 & 35 & 51 & 4 & 6 & 8 & 194 \\
Moribund fish $^{2,3}$ & 2 & 0 & 2 & 3 & 3 & 0 & 0 & 2 & 2 & 14 \\
Sacrificed for histology $^{2}$ & 0 & 16 & 6 & 6 & 9 & 3 & 4 & 8 & 4 & 56 \\
Sacrificed for triglycerides $^{2}$ & 0 & 12 & 0 & 0 & 0 & 0 & 0 & 0 & 0 & 12 \\
Handling mortality $^{2}$ & 0 & 0 & 0 & 1 & 5 & 0 & 0 & 0 & 0 & 6 \\
Accidently released $^{2}$ & 1 & 0 & 0 & 0 & 0 & 0 & 0 & 1 & 0 & 2 \\
Defective tag $^{4}$ & 0 & 0 & 0 & 0 & 0 & 1 & 0 & 0 & 0 & 1 \\
Sacrificed at end of study $^{5}$ & 8 & 0 & 13 & 0 & 2 & 0 & 0 & 38 & 49 & 110 \\
\hline
\end{tabular}

${ }^{1}$ Natural mortality.

${ }^{2}$ Throughout study (excludes sacrifices on September 15, 2014).

${ }^{3}$ Preserved for histology.

${ }^{4}$ The individual fish with a defective tag was not included in the survival or movement analyses.

${ }^{5} \mathrm{~A}$ subset of these fish were preserved for histology. 


\section{Water Quality}

Water-quality variables were measured hourly near the top (surface) and bottom (benthos) of the water column in order to examine sucker response to changing conditions. Temperature, DO concentration, and pH were measured hourly from July 9 to September 15, 2014, on four YSI 600XLMM sondes. Sondes were positioned $30 \mathrm{~cm}$ from the top (hereinafter, "Surface") and bottom (hereinafter, "Benthos") of the water column. Sonde depths were adjusted each Wednesday, when necessary, to account for declining lake elevations and mesocosm depth. Field sondes were retrieved each week, cleaned, and exchanged with laboratory-calibrated replacement field sondes. Upon retrieval, a reference sonde was used to measure water-quality parameters at Surface and Benthos sonde sites. Field sondes were cleaned and water-quality parameters of field and reference sondes were recorded to quantify deviance. When field retrieval readings deviated substantially (temperature $>0.4{ }^{\circ} \mathrm{C}, \mathrm{DO}>0.8 \mathrm{mg} / \mathrm{L}$, or $\mathrm{pH}>0.4$ ) from reference sonde readings, minor adjustments in that water-quality parameter field readings were made by regressing the difference across the week of readings. Instances of substantial deviation were rare, and small deviations were not altered. Spurious outlier data points were removed.

To assess sucker health and survival relative to un-ionized ammonia concentrations, we collected weekly point water samples in the middle of the water column using a peristaltic water pump, calibrated sonde, and acid washed Masterflex ${ }^{\circledR}$ tubing. All field and laboratory equipment used to sample un-ionized ammonia and microcystin was cleaned in the laboratory using Liquinox ${ }^{\mathrm{TM}}$ (Alconox) according to U.S. Geological Survey (USGS) protocol (U.S. Geological Survey, 2004). Ammonia tubing also was acid washed with a 5 percent $\mathrm{HCl}$ solution in the laboratory then rinsed with $900 \mathrm{~mL}$ of lake water prior to sample collection. Sample bottles were rinsed with deionized (DI) water three times and filled with approximately $60 \mathrm{~mL}$ DI water for transport to the field. Capsule filters were flushed with $2 \mathrm{~L}$ of DI water in the laboratory. Samples $(125 \mathrm{~mL})$ were collected after sample bottles were rinsed with three field rinses through one single capsule filter. Replicate samples were collected using a second capsule filter. Replicate and split samples were collected alternate weeks for quality control. Blank un-ionized ammonia samples were collected each week prior to the collection of field samples using the same protocol as field samples and inorganic blank water (Ricca Chemical Company LLC). Un-ionized ammonia samples were stored on ice during transport and refrigerated at $4{ }^{\circ} \mathrm{C}$ for up to 2 days until accepted by the Klamath Tribes Sprague River Water Quality Laboratory. Samples were then refrigerated for up to 10 days at $4{ }^{\circ} \mathrm{C}$ before they were analyzed. Discrete analyzer methods by colorimetric determination were used to quantify un-ionized ammonia as nitrogen by the Sprague River Water Quality Laboratory according to U.S. Environmental Protection Agency (1979) protocols. (Craig Spoonemore, Klamath Tribes Sprague River Water Quality Laboratory, oral commun., 2015). The more toxic un-ionized ammonia $\left(\mathrm{NH}_{3}\right)$ concentrations were calculated from total un-ionized ammonia concentrations using $\mathrm{pH}$ and water temperature measured during sample collection (Fairchild and others, 2005). 
To assess sucker health and survival relative to microcystin concentrations, we collected $1 \mathrm{~L}$ (two $500 \mathrm{~mL}$ samples) of depth-integrated water samples each week. Split samples were collected from the same sample as the primary to test for within sample variation while replicate samples were collected from a second water sample to test for environmental variation. Blank samples were collected on July 16, August 13, and September 10, 2014, prior to the collection of any field samples using organic blank water (EMD Millipore Corporation $\left.{ }^{(}\right)$. All sample collection equipment, including cage sampler bottles, churn splitter, and $500 \mathrm{~mL}$ borosilicate amber glass sample bottles, were field-rinsed prior to sample collection. All samples were depth-integrated and churned according to USGS protocol during collection (U.S. Geological Survey, 2006).

Field microcystin samples were filtered through a $63-\mu \mathrm{m}$ sieve to separate colonies of phytoplankton from the rest of the sample. The fraction of the sample retained on the sieve was considered the particulate fraction and the filtrate from the sieving process was considered the dissolved fraction. The particulates were concentrated and re-suspended in tap water after filtering. The total volume of the sample and the volume of tap water used to concentrate and re-suspend the particulates were recorded and later used to calculate the concentration factor. Both particulate and dissolved fractions were processed through three freeze-thaw cycles to lyse cells prior to analysis. Samples were filtered through either a 0.45 - or $0.30-\mu \mathrm{m}$ filter, depending on the filtering supplies available at the time. Filters were either $0.45-\mu \mathrm{m}$ UniPrep $^{\mathrm{TM}}$ syringeless glass microfiber filters (Whatman, Inc., Clifton, New Jersey) or $0.30-\mu \mathrm{m}$ pre-fired glass filters $\left(\right.$ Advantec $\left.^{\circledR}\right)$. The $0.30-\mu \mathrm{m}$ filters were used with a glass filter holder, glass filter flask, and vacuum hand-pump. Dilutions of both particulate and dissolved fractions were performed, when necessary, to bring the sample within the detection range of the analysis. Particulate and dissolved fractions were both analyzed for microcystin concentration using an enzymelinked immunosorbent assay (ELISA, kit PN 520011, Abraxis ${ }^{\circledR}$ LLC, Warminster, Pennsylvania). Sample absorbances were measured at $450 \mathrm{~nm}$ and calibration standards were analyzed with the samples. Microcystin concentrations were calculated using the regression from the calibration standards. Concentrated particulate results were multiplied by the concentration factor (volume of re-suspended particulates/volume of field sample) to determine the final microcystin concentration for the particulate samples.

\section{Movement}

Daily movement patterns of all living suckers were summarized by summing the number of remote contacts within each hour at the benthos and surface antennas and divided by the total number of live remote contacts from these antennas to obtain an activity index at each depth. These diurnal movement patterns were separated into three subseasons-Early (July 2- 28), Middle (July 29- August 21), and Late (August 22 - September 15) to assess variation in diurnal movement throughout the season. 


\section{Mortality and Survival}

Movement patterns of found dead fish were individually assessed and each fish was assigned an expected date and time of mortality based on individual movement patterns. In all cases, living remote detection patterns exhibited frequent ( $\leq 30$ minutes) detection among antennas, whereas non-living remote detection patterns exhibited intermittent to frequent detection at one antenna for prolonged (hours to days) periods. In most cases (96 percent), mortality was confirmed within 5 days of when the body was retrieved from the mesocosm. The design of this study was not intended to assess mechanisms causing variation in mortality among groups nor to assess how mortality varied by age (groups 1-7 versus 8-9). The purpose of introducing fish in groups was to estimate the carrying capacity of the mesocosm for future studies and to assess the ability of the technology to manage differential loads.

Kaplan-Meier (known fate) models were used to estimate daily survival of 276 age-1 Lost River suckers in the mesocosm over 76 days (Kaplan and Meier, 1958). Remote detections among antennas were used to create live-dead encounter histories and competing models were ranked in Program MARK. Pollock's staggered entry design was used to specify temporal variation in groups. Survival parameters for these groups were fixed $(\phi=1)$ prior to introduction of each group. Healthy sacrificed individuals were censored out of the population and did not contribute to subsequent survival estimates. Moribund sacrificed individuals were not censored out of the population and were assigned a mortality date as the date collected.

The assumptions associated with staggered entry Kaplan-Meier models of tagged animals are:

1. tags are not lost,

2. tag failure does not occur,

3. tagged population is a random and a representative sample of the larger population,

4. detection probability is 1.0 ,

5. status (alive or dead) of each individual is known at each sampling occasion (each day for this study),

6. time intervals are similar among occasions,

7. individual animals have independent survivals,

8. newly tagged or introduced animals have the same probability of surviving to time $(\mathrm{t}+\mathrm{i})$ as animals already present in the study,

9. survival rates are constant over defined intervals ( 1 day in this study),

10. survival does not vary among groups in staggered entry, and

11. censoring is random and not related to fate. 
The design of this study made assessing possible violations easy. We had no instances of tag loss within the study because we allowed tag wounds to heal 20 or more days prior to introduction, and all fish were screened for tag presence prior to being introduced to the mesocosm (1 and 8). We had one instance of tag failure where the tag was cracked and the fish was only detected four times in 7 days (2). This fish was not included in any analyses because its date of mortality and movement patterns could not be assessed. The population was fully represented because the tagged population was the entire population (3). We were able to account for all but one (cracked tag) age-1 fish (276/277) each day (4). The frequent detections among antennas allowed us to easily identify the day (sampling occasion) of mortality (5). All time intervals were short (24 hours) and representative of our ability to estimate timing of mortality (6 and 9). We assumed independence of survival among individuals based on the biology of the species because we did not directly observe schooling behavior (7). We accounted for variation in survival among newly introduced fish by testing for a group effect in the model design (8 and 10). Censoring was random because up to five fish were randomly selected for sacrifice 2 and 4 weeks after introduction (11). Fish with external lesions or parasites were not preferentially sacrificed unless they were moribund in which case they were not censored (11).

A set of a priori water quality hypotheses were tested against full and simplified group and time models to describe potential causes of daily sucker mortality. We tested daily, weekly, linear, and quadratic time trends. Daily water quality hypotheses included conditions such as mean, minimum, or maximum DO concentration, temperature, or $\mathrm{pH}$, and weekly microcystin or un-ionized ammonia concentrations (table 3 ). In addition, we tested three hypotheses summarizing total hours each day above $25^{\circ} \mathrm{C}$, or $\mathrm{pH} 9$, or DO concentrations below $4.0 \mathrm{mg} / \mathrm{L}$. These values are extreme relative to the conditions observed in the mesocosm yet conservative in relation to known high stress thresholds for Lost River suckers $\left(28^{\circ} \mathrm{C}, \mathrm{pH}\right.$ of 9.75 , and DO concentrations less than $2.1 \mathrm{mg} / \mathrm{L}$; Loftus, 2001; Meyer and Hansen, 2002). All water-quality parameters were standardized $[\bar{x}=0.0$, standard deviation $(\mathrm{SD})=$ $1.0]$ and assessed as time varying covariates. We also tested a model that tested for stress induced mortality on sampling days. Models with inestimable parameters were removed from the model set and are not included in the Akaike's information criterion (AICc) table. All models were run using the logit link function in program MARK.

All models were ranked using $\mathrm{AIC}_{\mathrm{c}}$ to account for small sample size (Burnham and Anderson, 2002). Models within two $\mathrm{AIC}_{\mathrm{c}}$ units were considered competitive (Burnham and Anderson, 2002). The relative likelihood of each model was assessed using Akaike weights, which rank the probability of each proposed model in a model set given the data (Burnham and Anderson, 2002). Models with high Akaike weights have more evidence to support the relative likelihood of that model (Burnham and Anderson, 2002). Model pairs can be compared using evidence ratios, which are the ratio of one model's Akaike weight relative to another (Burnham and Anderson, 2002). Evidence ratios that are low suggest model selection uncertainty while high evidence ratios suggest strong support for one model relative to a second model (Burnham and Anderson, 2002). Classical methods for estimating goodness-of-fit (Program RELEASE, median $\hat{c}$, bootstrapping) are not available for known fate models, so we investigated the robustness of model rankings by inflating $\hat{c}$ from 1.0 (no dispersion) to 3.0 (extreme over dispersion) to simulate different amounts of dispersion as ranked in the quasi-AIC ${ }_{\mathrm{c}}$ (Devries and others, 2003; Smith and others, 2015). 
Table 3. Description of a priori hypotheses tested to describe juvenile Lost River sucker mortality within the mesocosm in Upper Klamath Lake, Oregon.

$[\varphi$, survival $]$

\begin{tabular}{|c|c|c|c|}
\hline Model type & Model name & Description & $\begin{array}{l}\text { Number of } \\
\text { parameters }\end{array}$ \\
\hline \multicolumn{4}{|l|}{ Group and time } \\
\hline & $\varphi(g * t)$ & interactive group and daily time & 532 \\
\hline & $\varphi(g+t)$ & additive group and daily time & 82 \\
\hline & $\varphi(\mathrm{g})$ & group & 7 \\
\hline & $\varphi(g *$ quad $)$ & interactive group and quadratic time trend & 15 \\
\hline & $\varphi(\mathrm{g}+\mathrm{quad})$ & additive group and quadratic time trend & 15 \\
\hline & $\varphi(g * \operatorname{lin})$ & interactive group and linear time trend & 8 \\
\hline & $\varphi(g+\operatorname{lin})$ & additive group and linear time trend & 8 \\
\hline & $\varphi(\mathrm{t})$ & daily time & 76 \\
\hline & $\varphi($ week $)$ & weekly time & 11 \\
\hline & $\varphi$ (quad) & quadratic time trend & 3 \\
\hline & $\varphi(\operatorname{lin})$ & linear time trend & 2 \\
\hline & $\varphi$ (samp.stress) & excess stress induced on sampling days & 2 \\
\hline \multicolumn{4}{|l|}{ Water quality } \\
\hline & $\varphi($ temp.mean) & mean daily temperature & 2 \\
\hline & $\varphi($ temp.max $)$ & maximum daily temperature & 2 \\
\hline & $\varphi$ (temp.cv) & daily temperature coefficient of variation & 2 \\
\hline & $\varphi($ temp.25) & total hours of temperature greater than $25^{\circ} \mathrm{C}$ per day & 2 \\
\hline & $\varphi$ (DO.mean) & mean dissolved-oxygen concentrations & 2 \\
\hline & $\varphi($ DO.min $)$ & minimum dissolved-oxygen concentrations & 2 \\
\hline & $\varphi($ DO.cv) & $\begin{array}{l}\text { daily dissolved-oxygen concentrations coefficient of variation } \\
\text { total hours of dissolved oxygen concentration less than } 4 \mathrm{mg} / \mathrm{L}\end{array}$ & 2 \\
\hline & $\varphi(\mathrm{DO} .4)$ & per day & 2 \\
\hline & $\varphi$ (pH.mean) & mean daily $\mathrm{pH}$ & 2 \\
\hline & $\varphi(\mathrm{pH} . \max )$ & maximum daily $\mathrm{pH}$ & 2 \\
\hline & $\varphi(\mathrm{pH} . \mathrm{cv})$ & daily $\mathrm{pH}$ coefficient of variation & 2 \\
\hline & $\varphi(\mathrm{pH} .9)$ & total hours of $\mathrm{pH}$ greater than 9 per day & 2 \\
\hline & $\varphi\left(\mathrm{NH}_{3}\right)$ & weekly un-ionized ammonia concentrations & 2 \\
\hline & $\varphi($ conc.micro $)$ & weekly concentrated particulate microcystin concentration (ppb) & 2 \\
\hline & $\varphi($ diss.micro $)$ & weekly dissolved fraction microcystin concentration (ppb) & 2 \\
\hline \multicolumn{4}{|c|}{ (20) } \\
\hline
\end{tabular}




\section{Growth and Condition}

Individuals found dead were in various states of decay, which resulted in some fish lengths being unattainable. Length and weight measurements were taken from all sacrificed suckers. When possible, standard, fork, and total length measurements were taken from suckers retrieved shortly after death. SL and weight (wt) were used to compute body condition (that is, the Fulton condition factor; K $=\left[\mathrm{wt} / \mathrm{SL}^{3}\right] \times 10^{5}$ ) and assess growth. Total changes in SL, weight, and body condition were plotted for individuals that spent more than 3 weeks in the mesocosm, and linear regressions were fit to these data.

A total of 12 suckers from group 2 were sacrificed using an overdose of MS-222, 3 (n = 5), 6 (n $=5)$, and $8(\mathrm{n}=2)$ weeks following introduction for whole-body triglyceride analysis. One sample (sacrificed during week 6) was accidentally discarded before it was quantified (triglycerides analyzed, $\mathrm{n}$ =4). Five age-1 suckers from the Klamath Tribes Fish Research Facility, which were never introduced to the mesocosm, also were sacrificed for triglyceride analysis. These fish represented a starting condition for comparison with mesocosm fish. A decrease in triglycerides would indicate a lack of feeding in the mesocosm, whereas a flat or increasing trend in triglycerides over time would indicate adequate food resources in the mesocosm. Suckers were transferred from the field or fish research facility to the laboratory on dry ice where they were stored at $-80^{\circ} \mathrm{C}$ until they could be processed. Fish were homogenized with $1 \mathrm{~mL}$ of DI water per $1 \mathrm{~g}$ of fish in a blender or a Biospec M133 homogenizer. A small subsample $(0.2-0.5 \mathrm{~g})$ of fish puree was diluted at a 4 to 1 ratio of isopropyl alcohol (2propanol) to fish sample. Samples were rotated for 20 minutes and centrifuged for 5 minutes at 3,220 gravitation force. Diluted supernatant was assayed for triglycerides (milligrams of triglycerides per gram of tissue) using a Powerwave 340 colorimeter (BIO-TEK), Pointe Scientific triglyceride glycerol phosphate oxidase (GPO) kits, and methods from Weber and others (2003). A t-test was used to test for differences in triglyceride levels between mesocosm suckers and wild, age-0 suckers captured near the mesocosm during the summer 2014.

\section{Sucker Health and Determination of Cause of Death}

Throughout this study, 23.3 percent $(\mathrm{n}=92)$ of suckers were sacrificed for histological examination. Of these, 33 were selected a posteriori for full histopathological examination. Moribund (n $=14)$ fish collected from July 29 to September 11 and non-moribund $(n=19)$ fish collected August 4 and August1 1 during the July 28-August 16 mortality event were identified as high priority and were used to assess fish health in the mesocosm. Fish were sacrificed using an overdose of MS-222, external lesions and parasite loads were noted, and SL was measured. Field necropsies were performed postmortem on fish selected for histological examination to aid laboratory evaluation. Field necropsy evaluations identified gill color and shape, liver color and texture, spleen color, gall bladder color and distention, and presence and amount of visceral fat (Goede and Barton, 1990). Necropsies were quickly performed and all samples were preserved in Carson's modified Millonig phosphate-buffered formalin (Carson and others, 1973) within 5 minutes post-sacrifice. Fish were stored in formalin for 3-5 days and transferred to 70 percent ethanol. Samples were weighed in the laboratory. 


\section{Tissue Preparation for Histopathology}

Tissues collected for histopathological analysis included the gills, heart, anterior kidney, posterior kidney, liver, spleen, pancreatic tissue, and gastrointestinal tract. Skin and skeletal muscle were collected from fish with external lesions. All tissues were subjected to routine paraffin processing, sectioned at $5 \mu \mathrm{m}$ and stained with Gill's No. 3 hematoxylin and eosin (ThermoFisher Scientific) according to the manufacturer's instructions to determine the degree of host response and parasite occurrence. All tissues were examined by light microscopy with a Zeiss Axiophot photomicroscope, and the degree of host response, including inflammation and cell necrosis per $200 \times$ field, was recorded and scored using a four-point scale. Tissue distribution of host response was scored as none, focal, multifocal or diffuse; severity was scored as none, minimal to mild, moderate, or severe. The location and identification of parasites and the degree of host response to parasites also was recorded. The presence, appearance of vacuoles and staining characteristics of hepatocyte cytoplasm were used to explore liver energy storage as another possible indicator of the nutritional status of fish. Liver tissue was stained with periodic acid-Schiff (PAS) and PAS-diastase to estimate the amount of glycogen stored in hepatocyte cytoplasm. Glycogen distribution was rated as none, focal (low levels), or multifocal to diffuse (high levels). The presence of hepatocellular vacuoles morphologically consistent with lipid storage also was noted.

\section{Results}

\section{Seasonal Variation in Depth, Temperature, Dissolved Oxygen, and pH}

The total depth of the mesocosm decreased by $0.5 \mathrm{~m}$ throughout the season (fig. 2) as lake elevation in Upper Klamath Lake declined. As a result, the water-quality readings from the Benthos sonde were taken at decreasing depths as the season progressed (fig. 2). The sharp peak in depth readings from August 18 to 20,2014, was due to improper replacement of the sonde chain after sacrificing the suckers for the week. During this time, depths were approximately $20 \mathrm{~cm}$ below the surface and $40 \mathrm{~cm}$ above the benthos.

Throughout the entire season, hourly water temperature ranged from 15.01 to $29.86{ }^{\circ} \mathrm{C}$. Mean daily water temperature generally decreased throughout the study season, but ranged from 17.55 to $25.62{ }^{\circ} \mathrm{C}$. Maximum daily water temperature ranged from 19.55 to $29.86^{\circ} \mathrm{C}$. On average, daily temperatures fluctuated $4.7 \pm 1.1^{\circ} \mathrm{C} \mathrm{SD}$ in the mesocosm throughout the season (fig. 3). Diel temperature differences between the Surface and Benthos sondes were similar to each other; the mean difference in hourly temperature was $0.38 \pm 0.61^{\circ} \mathrm{C}$. Temperature was highest July 9-19 when all hourly readings ranged from 21.8 to $29.9^{\circ} \mathrm{C}$ (fig. 3). At the end of the study season, in September, daily water temperatures ranged from 15.01 to $22.57^{\circ} \mathrm{C}$. Cool weather conditions on July $23-24$ and September 12-14 caused decreases in water temperature (fig. 3). Generally, the diel temperature coefficient of variation $(\mathrm{CV})$ increased slightly throughout the season. The mean diel temperature $\mathrm{CV}$ was $0.07 \pm 0.02 \mathrm{SD}$ and ranged from 0.03 to 0.13 . There was little variation in the standard deviation of diel temperature throughout the season $(1.46 \pm 0.43$, range $=0.67-2.65)$. 


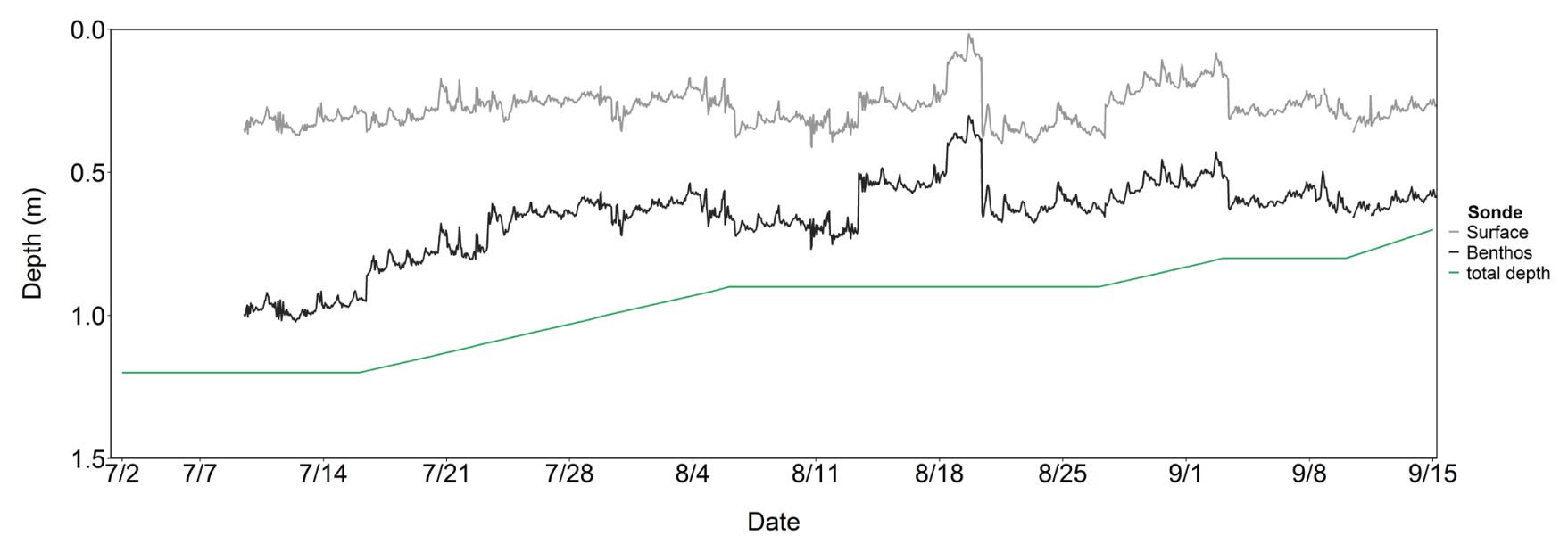

Figure 2. Water depth and depth of water quality readings in the mesocosm in Upper Klamath Lake, Oregon. Water quality samples collected July 9-September 15, 2014.

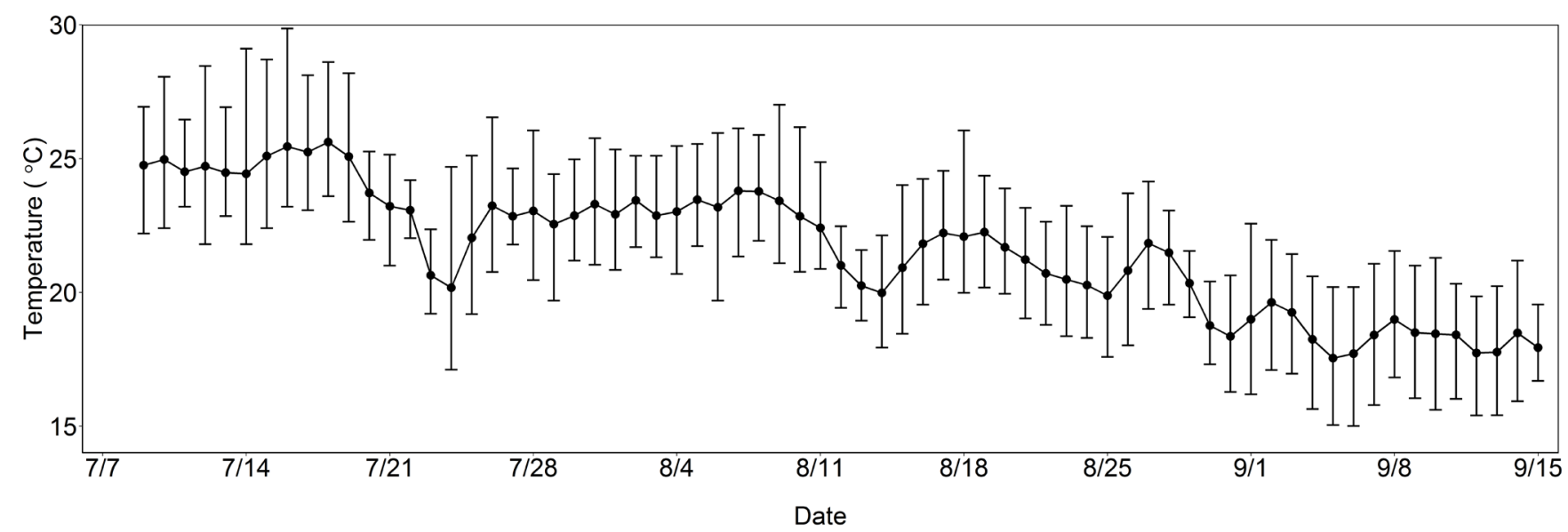

Figure 3. Mean (black circle), minimum (bottom bar), and maximum (top bar) daily water temperatures in the mesocosm in Upper Klamath Lake, Oregon, July 9-September 15, 2014. 
Mean daily DO concentrations $(8.97 \pm 1.74 \mathrm{mg} / \mathrm{L})$ and mean diel fluctuations in DO concentrations $(5.81 \pm 2.37 \mathrm{mg} / \mathrm{L})$ varied throughout the sampling season (fig. 4). Generally, DO concentrations were similar between Surface and Benthos sondes (average difference $0.75 \pm 1.18 \mathrm{mg} / \mathrm{L}$ ) except from July 12 to 15 when daily fluctuations were greatest (range $=8.14-14.46 \mathrm{mg} / \mathrm{L}$, minimum for period $=0.07$, maximum for period $=16.25 \mathrm{mg} / \mathrm{L}$ ) and concentrations reached seasonal lows (fig. 4). Extreme differences in DO concentration between the Surface and Benthos during this time may represent brief occurrences of lake stratification. DO concentrations usually increased and decreased gradually throughout the day, but on some days DO concentrations changed rapidly. Rapid increases may represent instances of lake stratification followed by mixing. Mean minimum daily DO concentrations were $6.21 \pm 2.16 \mathrm{mg} / \mathrm{L}$ in the mesocosm (fig. 4). There was little variation in the diel CV in DO concentrations throughout the season $(0.19 \pm 0.10$, range $=0.08-0.63)$, although diel $\mathrm{CV}$ was high July 14-15 (0.61-0.63). There was little variation in the SD of diel DO concentrations throughout most of the season $(1.65 \pm 0.72$, range $=0.63-4.67)$, although the SD was relatively high in mid-July. DO concentrations were less than $4.0 \mathrm{mg} / \mathrm{L}$ for 15 hours near the Surface and 72 hours near the Benthos over the entire 1,622 hour study period. DO concentrations were less than $4.0 \mathrm{mg} / \mathrm{L}$ at both Surface and Benthos sondes for 10 hours throughout the study season. The longest duration of DO concentrations less than $4.0 \mathrm{mg} / \mathrm{L}$ was on July 31 between 0400 and 1000 hours, when concentrations ranged from 3.28 to $3.93 \mathrm{mg} / \mathrm{L}$.

Mean $\mathrm{pH}$ in the mesocosm was high $(8.98 \pm 0.41)$ and ranged from 7.32 to 9.75 (fig. 5). Throughout the season, $\mathrm{pH}$ was often greater than 9, although $\mathrm{pH}$ was relatively low July 27-August 4. On average, $\mathrm{pH}$ fluctuated $0.81 \pm 0.42$ (average $\pm \mathrm{SD}$ ) per day, although there were several instances throughout the study (July 23-26, August 7-9, and August 29-September 15) when pH was high and diel fluctuations were small (fig. 5). Mean maximum daily $\mathrm{pH}$ was $9.35 \pm 0.25$ and ranged from 8.63 to 9.75. Mean minimum daily $\mathrm{pH}$ was $8.54 \pm 0.54$ and ranged from 7.32 to 9.26 . The mean difference between Surface and Benthos $\mathrm{pH}$ was $0.17 \pm 0.19$. Generally, $\mathrm{pH}$ at the Surface and Benthos fluctuated in tandem, but $\mathrm{pH}$ was usually slightly higher at the Surface than at the Benthos. 


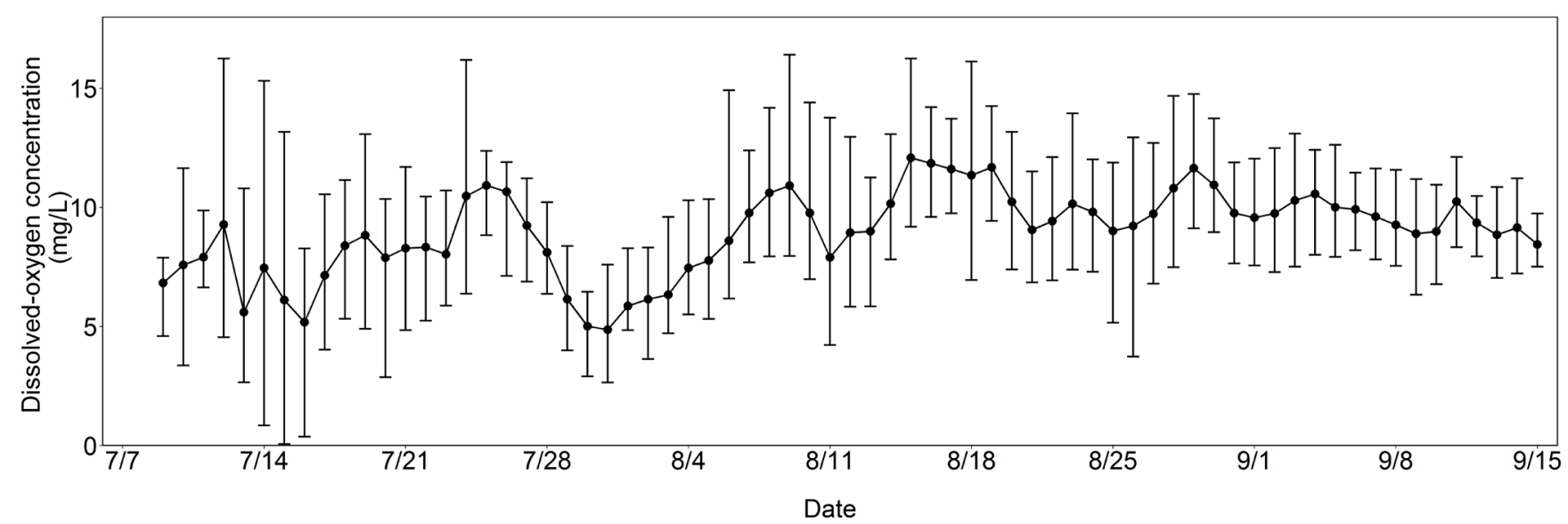

Figure 4. Mean (black circle), minimum (bottom bar), and maximum (top bar) daily dissolved-oxygen concentrations in the mesocosm in Upper Klamath Lake, Oregon, July 9-September 15, 2014.

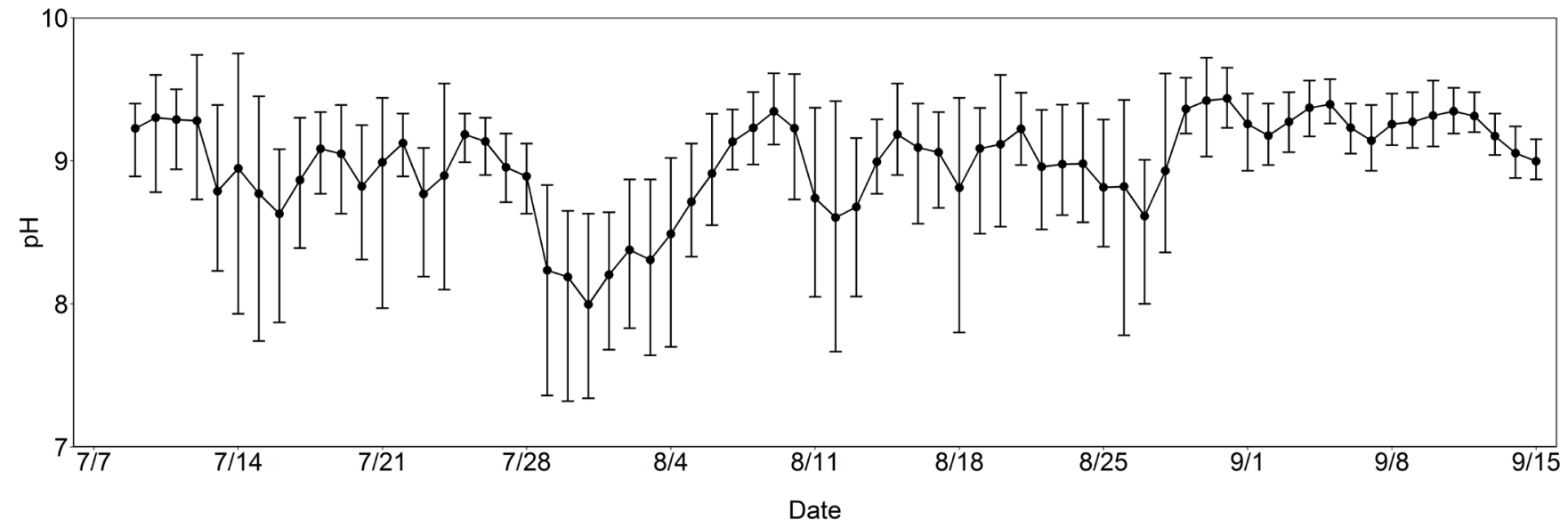

Figure 5. Mean (black circle), minimum (bottom bar), and maximum (top bar) daily pH in the mesocosm in Upper Klamath Lake, Oregon, July 9-September 15, 2014. 


\section{Microcystin}

Environmental variability of microcystin was low within sampling occasions. The difference between primary and replicate samples of dissolved fraction microcystin was $0.22 \pm 0.16 \mu \mathrm{g} / \mathrm{L}$ and ranged from less than 0.001 to $0.440 \mu \mathrm{g} / \mathrm{L}$. The difference between primary and replicate samples of concentrated particulate microcystin was $1.08 \pm 1.87 \mu \mathrm{g} / \mathrm{L}$ and ranged from 0.04 to $3.9 \mu \mathrm{g} / \mathrm{L}$. Variability within samples of microcystin also was low. The difference between primary and split samples of dissolved fraction microcystin was $0.07 \pm 0.07 \mu \mathrm{g} / \mathrm{L}$ and ranged from 0 to $0.17 \mu \mathrm{g} / \mathrm{L}$. The difference between primary and split samples of concentrated particulate microcystin was $0.34 \pm 0.36 \mu \mathrm{g} / \mathrm{L}$ and ranged from 0.01 to $0.79 \mu \mathrm{g} / \mathrm{L}$. Low variation between primary and replicate or primary and split samples suggest quality control was adequate throughout the season.

Microcystin concentrations in the particulate fraction $(\geq 63 \mu \mathrm{m})$ increased earlier and peaked much higher than the dissolved fraction. Concentrated particulate microcystin was low in July, increased quickly in August, and was highest (43.22 $\mu \mathrm{g} / \mathrm{L}$ ) August 20, 2014 (fig. 6a). Concentrated particulate microcystin levels stayed relatively high until the last week of the study (September 15) when concentrations decreased to less than $5 \mu \mathrm{g} / \mathrm{L}$.

Weekly samples of dissolved fraction microcystin were less than $1 \mu \mathrm{g} / \mathrm{L}$ through the week of August 17. Following 2 weeks of elevated concentrations in the particulate fraction, dissolved fraction concentrations increased sharply to $4.55 \mu \mathrm{g} / \mathrm{L}$ the week of August 20. Dissolved concentrations remained greater than $2 \mu \mathrm{g} / \mathrm{L}$ for 3 weeks in August and September (fig. 6b).
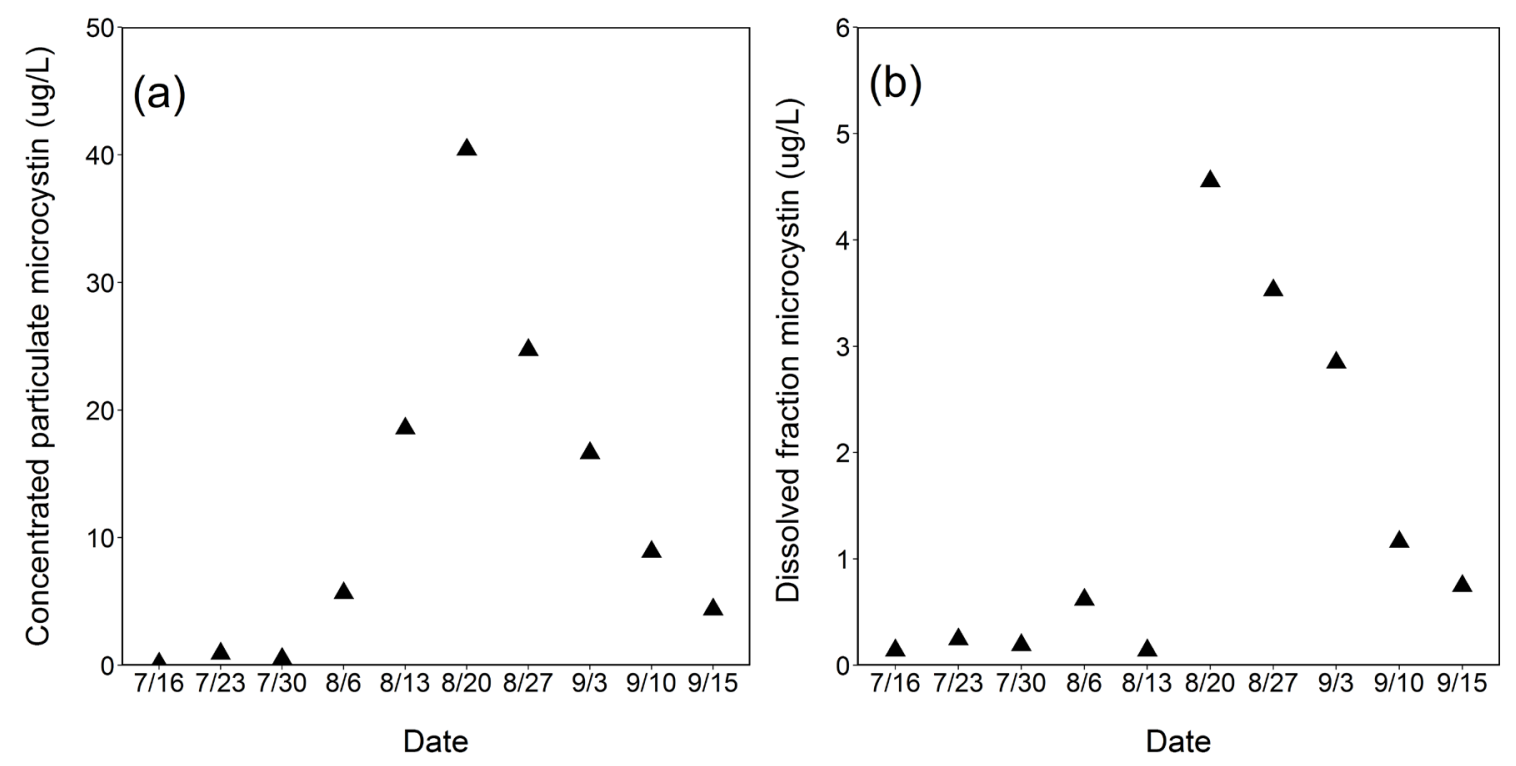

Figure 6. Concentrated particulate (a) and dissolved fraction (b) microcystin concentrations approximately 100 meters from the mesocosm in Upper Klamath Lake, Oregon, July 16-September 15, 2014. Note the difference between $y$-axis scales in these two graphs. 


\section{Un-lonized Ammonia}

Environmental variability of un-ionized ammonia was low within sampling occasions. The difference between primary and replicate samples of un-ionized ammonia was $1.97 \pm 1.76 \mu \mathrm{g} / \mathrm{L}$, and ranged from less than 0.85 to $4.60 \mu \mathrm{g} / \mathrm{L}$. Variability within samples of un-ionized ammonia also was low. The difference between primary and split samples of un-ionized ammonia was $2.63 \pm 3.54 \mu \mathrm{g} / \mathrm{L}$ and ranged from 0 to $7.83 \mu \mathrm{g} / \mathrm{L}$. Low variation between primary and replicate or primary and split samples suggest quality control was adequate throughout the season. Un-ionized ammonia concentrations varied among weeks; concentrations were highest July $16(103 \mu \mathrm{g} / \mathrm{L})$, decreased throughout July $(39-41 \mu \mathrm{g} / \mathrm{L})$, and were very low $(<30 \mu \mathrm{g} / \mathrm{L})$ throughout August and September (fig. 7).

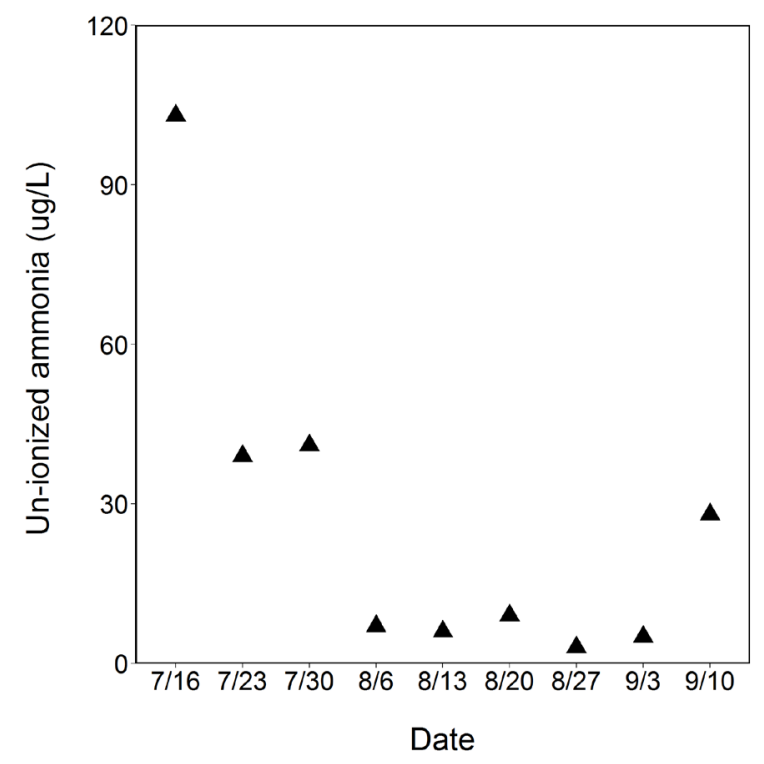

Figure 7. Un-ionized ammonia concentrations approximately 100 meters from the mesocosm in Upper Klamath Lake, Oregon, July 16-September 10, 2014. 


\section{Movement}

Suckers in the mesocosm exhibited vertical diurnal movement patterns. Suckers were detected most often on benthos antennas during daylight hours and throughout the water column at night (fig. 8). Suckers settled near the benthos around sunrise or between approximately 0400 and 0600 hours and began using the entire water column again around sunset, or between approximately 2000 and 2100 hours. This behavior was observed throughout the summer, but daytime use of the benthos was most distinct during late summer (August 22-September 15).

The timing of movement patterns was not associated with diurnal fluctuations in DO concentrations, $\mathrm{pH}$, or temperature. In the early season (July 2-28), DO concentrations, $\mathrm{pH}$, and temperature generally were higher near the surface than near the benthos, including when suckers were using the benthos and the whole water column. In mid-season (July 29-August 21), DO concentrations were on average higher near the benthos than the surface, while $\mathrm{pH}$ and temperature generally were the same throughout the water column when suckers spent more time on the bottom between 2100 and 0400 hours.

Finally, late in the season (August 22-September 15), DO concentrations were higher and temperature and $\mathrm{pH}$ were lower near the benthos than near the surface when suckers were on the bottom. The most extreme examples of non-avoidance of poor water quality occurred twice when DO concentrations were less than $1.58 \mathrm{mg} / \mathrm{L}$, the median 24-hour lethal concentration $\left(\mathrm{LC}_{50}\right)$ for juvenile Lost River suckers (Saiki and others, 1999). DO concentrations near the benthos were low on July 14 (0.85 mg/L at 1100 hours) and July 15 (<1.58 mg/L between 0200 and 0800 hours; fig. 9). During these times, most suckers spent more time near the Benthos than near the Surface where DO concentrations were higher $(11.72 \mathrm{mg} / \mathrm{L}$ on July 14 at 1100 hours and 3.38-9.35 mg/L on July 15 at 0200-0800 hours; fig. 9). Fish exhibited atypical behavior on July 15 by remaining near the benthos where DO concentrations were extremely low during dark hours. 


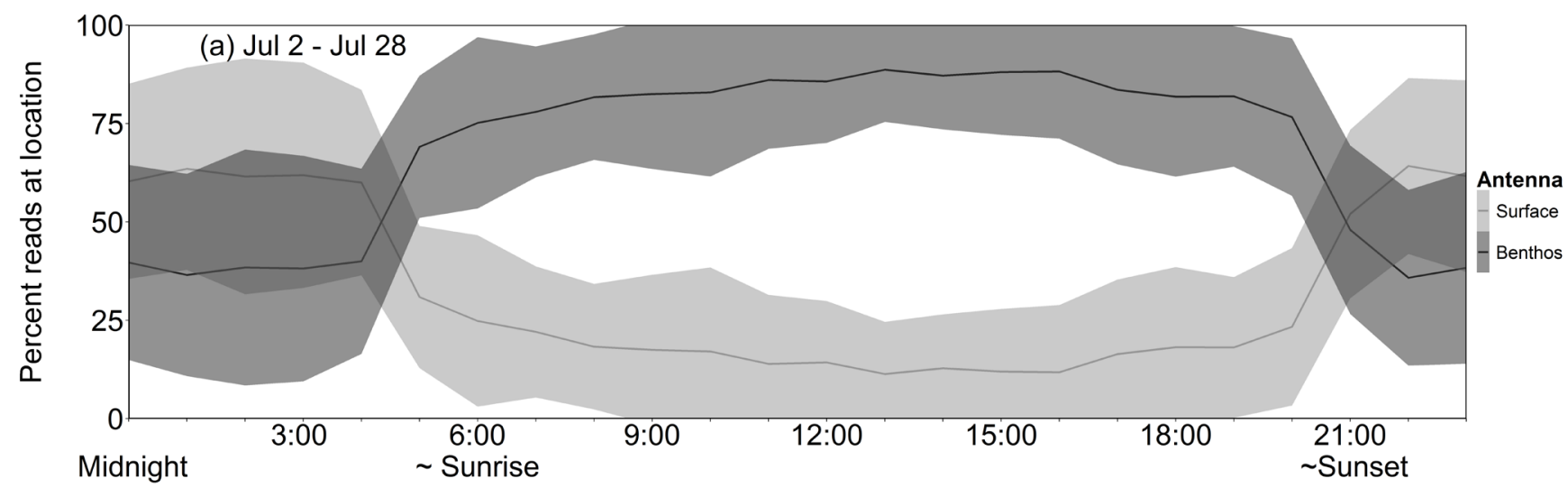

Time

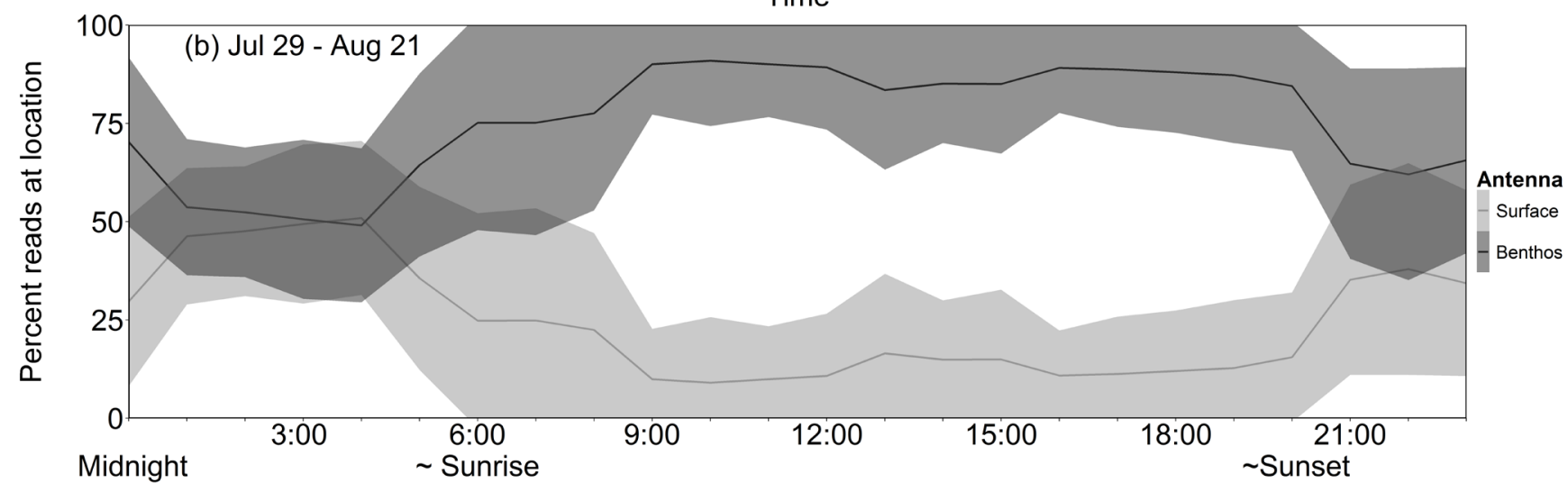

Time

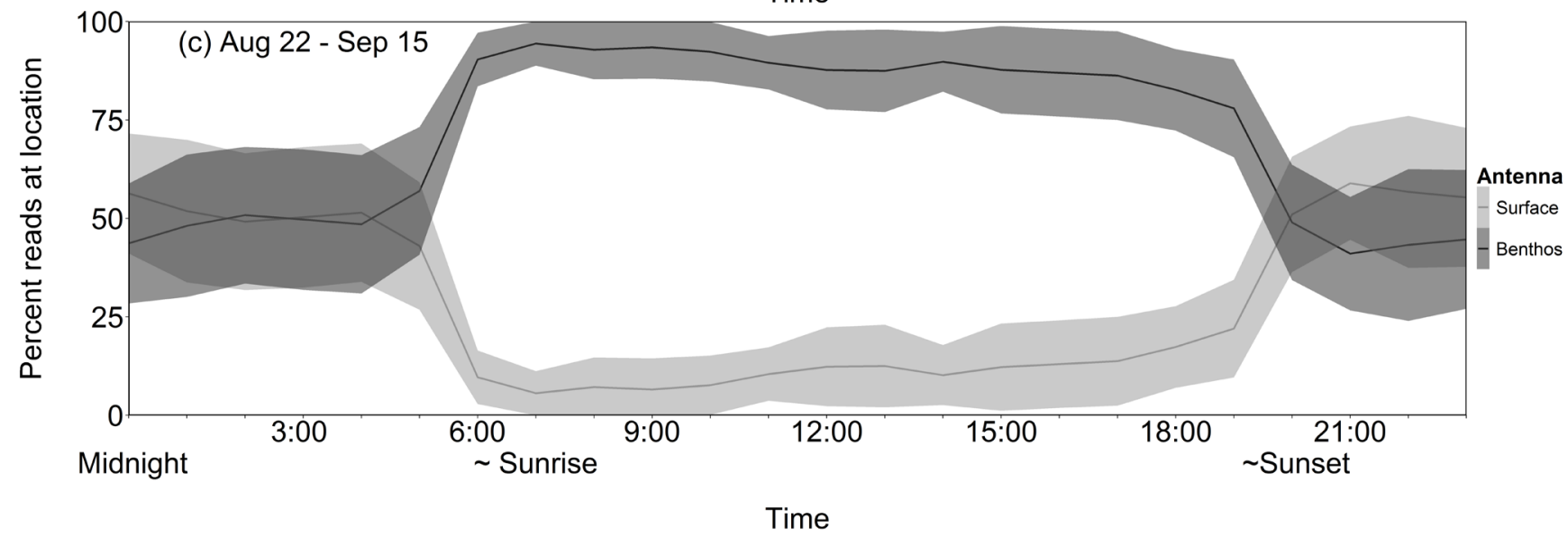

Figure 8. Diurnal vertical movement patterns of juvenile Lost River suckers in the mesocosm in Upper Klamath Lake, Oregon, summarized as percent reads per hour among Surface and Benthos antennas during (a) early (July 2-28), (b) middle (July 29-August 21), and (c) late (August 22-September 15) season. Line represents the average percentage of reads detected during each hour interval; ribbon represents one standard deviation. 

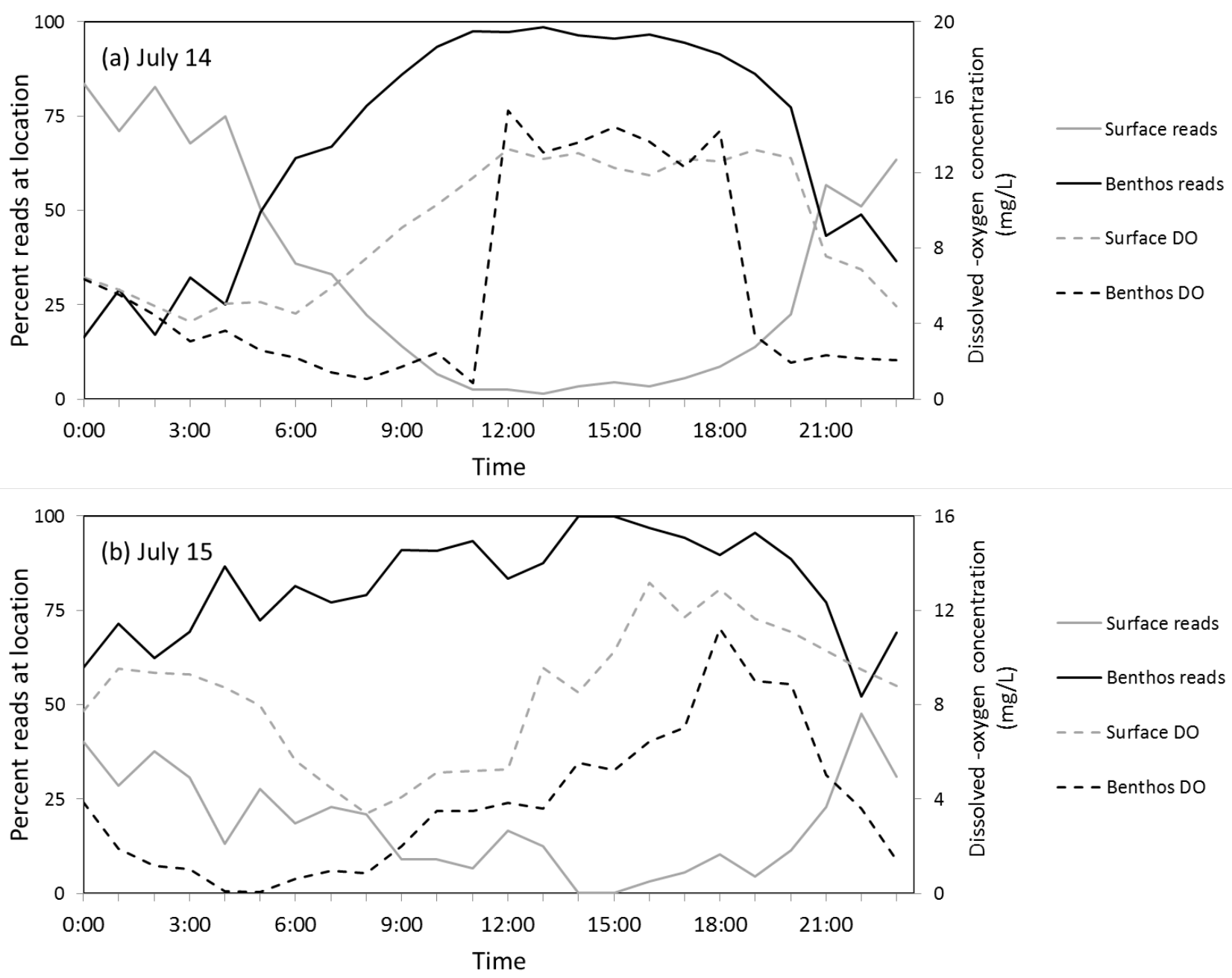

Figure 9. Percentage of hourly activity (reads) near benthic and surface antennas of juvenile Lost River suckers and dissolved-oxygen concentration (DO; mg/L) near surface and near benthos in the mesocosm in Upper Klamath Lake, Oregon, on (a) July 14, 2014, and (b) July 15, 2014. 


\section{Mortality}

A total of 52.7 percent $(n=208)$ of suckers died naturally (found dead or moribund) and lived an average of $18.5( \pm 15.5 \mathrm{SD})$ days. Mortality occurred on most $(39 / 76)$ days, but 83 percent $(\mathrm{n}=172)$ of all mortalities occurred between July 28 and August 16, 2014. All groups present had mortality during this time period, although some groups had more mortality than others (fig. 10). For example, during the 3-week period when most fish died, the majority were from groups $3,4,5$, and 6 , although a few were individuals from groups 1 and 2 . The variation in observed mortality among groups may have been due to cage density although the two factors are confounded and impossible to separate in model design.

The average number of days fish lived in the mesocosm also varied among groups (table 4, fig. 11). In general, fish that were introduced at the beginning of the study (groups 1 and 3) were alive for more days than fish introduced later (table 4). In part, days alive is directly related to the number of days available; however, groups that were introduced during the middle of the study (groups 4-6) did not live longer than groups introduced near the end (groups 7-9) (table 4). No fish from groups 2, 4, 6, or 7 lived until the end of the study (table 2, fig. 11). The majority of fish from group 2 (62.2 percent) were healthy and sacrificed prior to the end of the study for triglyceride and histology analysis, while the majority of fish from group 4 (80.0 percent) and group 6 (94.5 percent) were found dead of natural mortality. One-half of the fish from group 7 were found dead of natural mortality and one-half were healthy and sacrificed, although sample size from group 7 was very small $(\mathrm{n}=8$, table 2$)$.

Extreme water-quality conditions did not appear to directly cause mortality. Only two mortalities occurred during the time that water temperatures were highest $\left(21.8-29.9^{\circ} \mathrm{C}\right.$ between July 9 and July 19). No mortalities occurred during the time that DO concentrations reached their lowest recorded values on July 14 (0.85 mg/L at 1100 hours) and July 15 ( $<1.58 \mathrm{mg} / \mathrm{L}$ from 0200 to 0800 hours) (fig. 9); one mortality occurred on July 15 around 1630 hours when DO concentrations were between 6.59 and $7.05 \mathrm{mg} / \mathrm{L}$. This individual had been exclusively detected at the surface and middle antennas from 0400 to 0800 hours, where DO concentrations were relatively high $(3.38-8.73 \mathrm{mg} / \mathrm{L})$, in contrast to most of the other suckers, which were detected more often near the benthos (fig. 9b). 


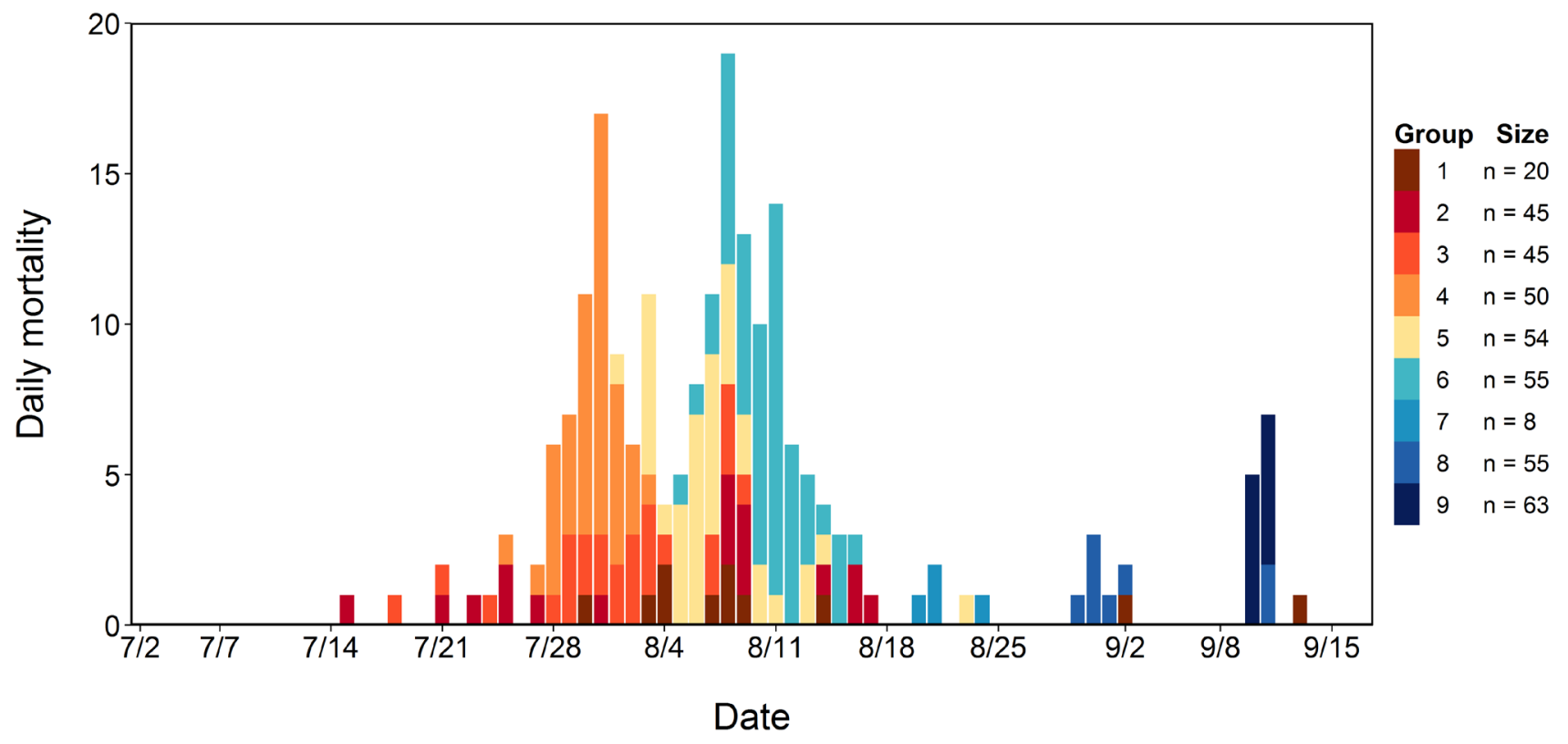

Figure 10. Total number of natural daily mortalities for age-1 (groups 1-7) and age-2 (groups 8 and 9) juvenile Lost River suckers in the mesocosm in Upper Klamath Lake, Oregon, July 2-September 15, 2014.

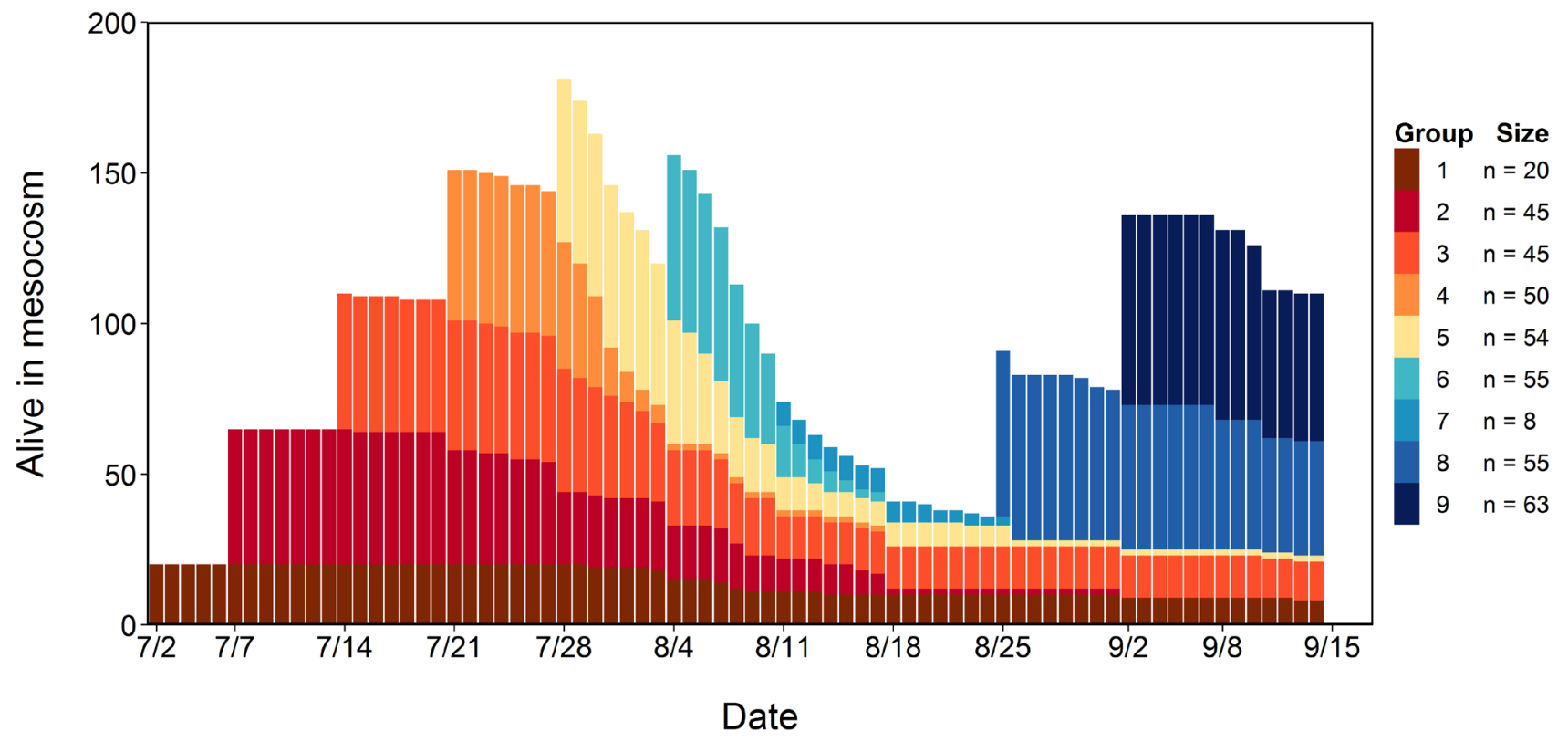

Figure 11. Total number of Lost River suckers alive in the mesocosm in Upper Klamath Lake, Oregon, July 2 September 15, 2014. Observed reductions in groups are due to natural mortality and scheduled sacrifices. 
Table 4. Average \pm standard deviation and maximum number of days one or more fish was alive in the mesocosm, and the total number of days available (from date of introduction to September 15) for each group of hatchery-raised Lost River suckers in the mesocosm in Upper Klamath Lake, Oregon, July 2-September 15, 2014.

\begin{tabular}{|c|c|c|c|c|c|}
\hline & \multicolumn{5}{|c|}{ Group } \\
\hline & 1 & 2 & 3 & 4 & 5 \\
\hline \multicolumn{6}{|l|}{ Days alive } \\
\hline All suckers ${ }^{1}$ & $55.4 \pm 20.0$ & $27.8 \pm 11.6$ & $33.0 \pm 20.8$ & $10.6 \pm 4.2$ & $13.3 \pm 9.7$ \\
\hline Natural mortalities ${ }^{1}$ & $39.7 \pm 13.2$ & $27.8 \pm 10.3$ & $18.3 \pm 5.6$ & $9.5 \pm 1.8$ & $9.9 \pm 3.9$ \\
\hline Natural mortalities and sacrificed at end ${ }^{1}$ & $55.4 \pm 20.1$ & $27.8 \pm 10.3$ & $33.0 \pm 21.9$ & $9.3 \pm 2.0$ & $11.5 \pm 9.0$ \\
\hline Maximum & 75 & 41 & 63 & 13 & 49 \\
\hline \multirow[t]{3}{*}{ Total days available } & 75 & 70 & 63 & 56 & 49 \\
\hline & \multicolumn{5}{|c|}{ Group } \\
\hline & 6 & 7 & 8 & 9 & All \\
\hline \multicolumn{6}{|l|}{ Days alive } \\
\hline All suckers ${ }^{1}$ & $6.9 \pm 2.8$ & $11.8 \pm 3.2$ & $18.4 \pm 4.8$ & $12.0 \pm 1.8$ & $18.5 \pm 15.5$ \\
\hline Natural mortalities ${ }^{1}$ & $6.5 \pm 6.5$ & $10.5 \pm 1.7$ & $7.8 \pm 4.5$ & $8.4 \pm 0.5$ & $12.7 \pm 9.9$ \\
\hline Natural mortalities and sacrificed at end ${ }^{1}$ & $6.5 \pm 2.3$ & $10.5 \pm 1.7$ & $18.9 \pm 5.0$ & $12.2 \pm 1.7$ & $17.6 \pm 16.1$ \\
\hline Maximum & 12 & 13 & 21 & 13 & - \\
\hline Total days available & 42 & 35 & 21 & 13 & - \\
\hline
\end{tabular}

${ }^{1}$ Average \pm standard deviation.

\section{Survival}

The top-ranked model was an interactive model that accounted for variation among groups and had quadratic time trends ( $\mathrm{g} *$ quad). This model had 99.87-100 percent of the $\mathrm{AIC}_{\mathrm{c}}$ weight for all measures of dispersion $(\hat{\mathrm{c}}=3.0-1.0)$ and included 15 parameters (table 5$)$. The fully saturated model ( $\mathrm{g}$ $* t$ ) was removed from the model set because many of the 532 parameters were inestimable and this model was over-parameterized, having more parameters than fish $\left(\mathrm{n}_{\mathrm{fish}}=276\right)$ in the study. The second ranked model was constrained to group variation with an additive quadratic time trend (g + quad) and the third ranked model had only a quadratic time trend (quad; table 5). The second model had 0.13 percent weight of the $\mathrm{AIC}_{\mathrm{c}}$ weight when $\hat{\mathrm{c}}=3.0$ but zero weight when $\hat{\mathrm{c}}$ was less than 2.8 . The top seven ranked models were ranked in the same order for all measures of dispersion. Mean daily temperature and mean daily DO concentration models each explained more variation than the constant (dot) model, although they failed to describe variation when combined and failed to describe variation in survival in a meaningful way (table 5). These models failed to describe more variation than the constant model when $\hat{\mathrm{c}}$ was greater than 1.07 for mean daily temperature and 1.26 for mean daily DO concentration model. Other models that included time varying water-quality parameters, such as mean, maximum, minimum, or number of days above or below a specific temperature, $\mathrm{DO}, \mathrm{or} \mathrm{pH}$; or weekly un-ionized ammonia concentrations and weekly microcystin concentrations, failed to explain the observed variation in survival in a biologically meaningful way, so they were not considered further and were removed from the $\mathrm{AIC}_{\mathrm{c}}$ table. 
We used the top-ranked model to assess how survival varied temporally and among groups because we were interested in identifying the timing of mortality and how mortality varied among groups due to the study design. All inferences about survival were derived from the top ranked model, ( $\mathrm{g} *$ quad). Daily survival was highest for groups 1,2 , and 3 (range ${ }_{\mathrm{g} 1}=95-100$ percent, range ${ }_{\mathrm{g} 2, \mathrm{~g} 3}=$ 94-100 percent). Daily survival was lower for groups 4 and 5 (range ${ }_{g 4}=77-99$ percent, range $e_{g}=89$ 100 percent, range $\mathrm{g}_{\mathrm{g}}=83-100$ percent), and lowest for group 6 (range $\mathrm{g}_{6}=49-97$ percent). Late season daily survival for groups 6 and 7 was difficult to estimate, and 95-percent confidence intervals were large (fig. 12) due to high mortality, although estimates for group 7 also were limited by small initial sample size $(\mathrm{n}=8)$. For days and groups with smaller 95-percent confidence intervals (groups 1 through 5), daily survival was lowest the last week in July and the first 2 weeks of August. In general, survival was high (95-100 percent) from late August until the study was terminated September 15.

Table 5. Model selection results for Kaplan Meier models fit to estimate daily survival of age-1 juvenile Lost River suckers in the mesocosm in Upper Klamath Lake, Oregon, July 2-September 15, 2014.

[( $\hat{c}=1.0) . \varphi=$ survival. Models that failed to interact with survival as hypothesized were removed from the model rankings. For example, the mean daily $\mathrm{pH}$ model was removed because it estimated survival to be lowest when $\mathrm{pH}$ was low (least stressful) and survival to be highest when $\mathrm{pH}$ was high (most stressful). All models considered are listed and explained in table 3]

\begin{tabular}{|c|c|c|c|c|c|}
\hline & Model & $\mathrm{AlC}_{\mathrm{c}}$ & $\Delta \mathrm{AlC}_{\mathrm{c}}$ & $\mathrm{AIC}_{\mathrm{c}}$ weights & $\begin{array}{l}\text { Number of } \\
\text { parameters }\end{array}$ \\
\hline 1 & $\varphi(\mathrm{g} * \mathrm{quad})$ & 1398.5 & 0 & 1.0 & 15 \\
\hline 2 & $\varphi(\mathrm{g}+\mathrm{quad})$ & 1462.5 & 64.0 & 0 & 9 \\
\hline 3 & $\varphi$ (quad) & 1522.2 & 123.8 & 0 & 3 \\
\hline 4 & $\varphi(g * \operatorname{lin})$ & 1546.1 & 147.6 & 0 & 8 \\
\hline 5 & $\varphi(g+\operatorname{lin})$ & 1561.9 & 163.5 & 0 & 8 \\
\hline 6 & $\varphi(\mathrm{g})$ & 1570.3 & 171.8 & 0 & 7 \\
\hline 7 & $\varphi(\operatorname{lin})$ & 1704.5 & 306.1 & 0 & 2 \\
\hline 8 & $\varphi$ (DO.mean) & 1715.1 & 316.7 & 0 & 2 \\
\hline 9 & $\varphi($ temp.mean) & 1715.5 & 317.1 & 0 & 2 \\
\hline 10 & $\varphi()$. & 1715.7 & 317.2 & 0 & 1 \\
\hline 11 & $\varphi$ (DO.mean + temp.mean) & 1716.4 & 317.9 & 0 & 3 \\
\hline
\end{tabular}




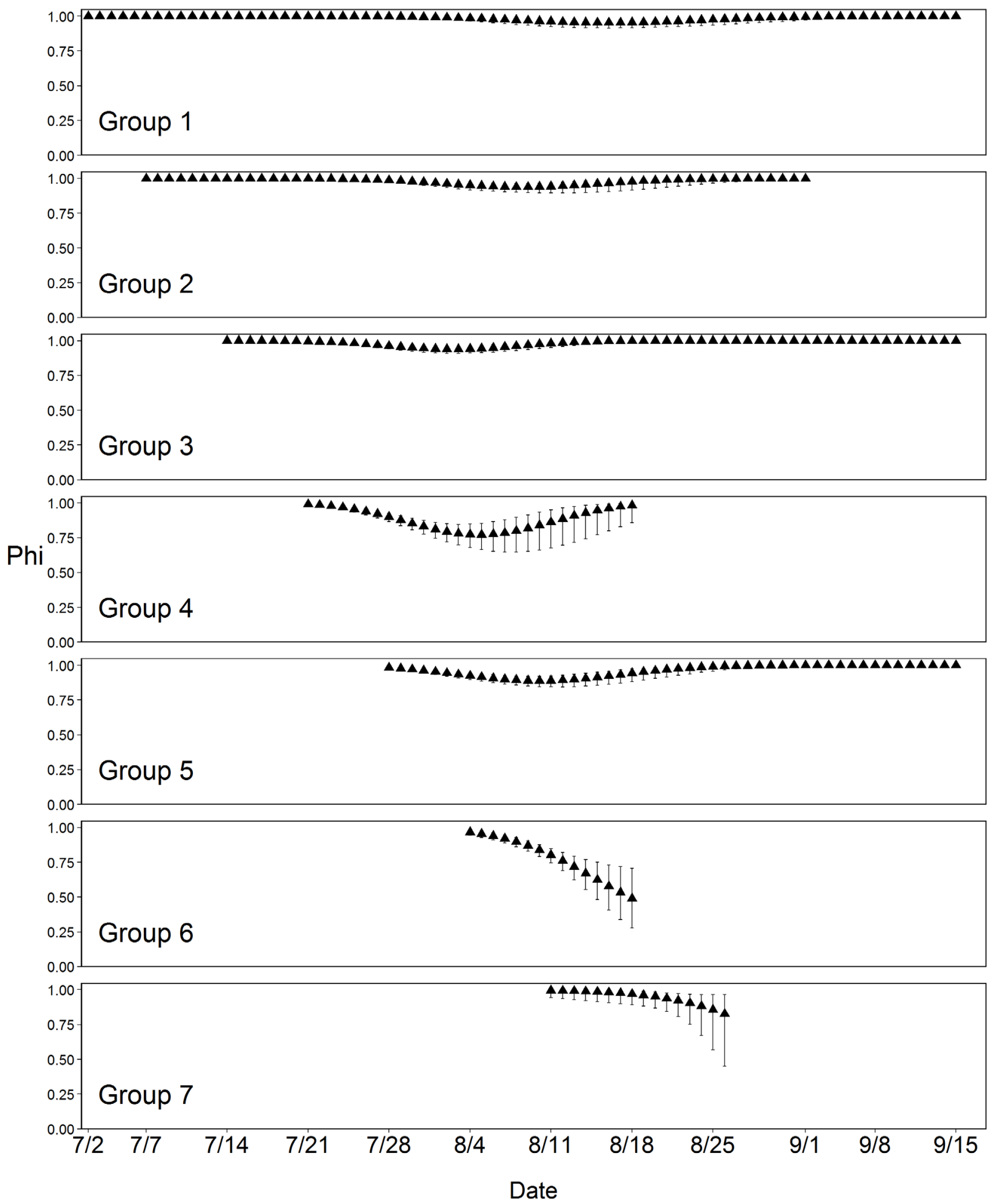

Figure 12. Daily survival estimates and 95-percent confidence intervals for age-1 juvenile Lost River suckers in the mesocosm in Upper Klamath Lake, Oregon, July 2-September 15, 2014. Estimates derived from the top-ranked time model in Program MARK (table 5). Survival estimates terminate at end of the study (groups 1,3, and 5) or on the last day fish from that group were alive in the mesocosm (groups 2, 4, 6, and 7). 95-percent confidence intervals derived from $\hat{c}=1.0$. 


\section{Growth and Condition}

Of the suckers that spent at least 3 weeks in the mesocosm, most increased in SL (90.0 percent; $n$ =114/127; fig. 13), weight (97.8 percent; 91/93; fig. 14), and body condition (84.9 percent; 79/93; fig. $15)$ while in the mesocosm. Changes in $\mathrm{SL}\left(\mathrm{SL}=0.74\right.$ (days)-11.92, $\mathrm{R}^{2}=0.81$, $\left.\mathrm{df}=125, \mathrm{p}<0.01\right)$, weight (wt $=0.42$ (days)-3.95, $\left.\mathrm{R}^{2}=0.76, \mathrm{df}=91, \mathrm{p}<0.01\right)$, and body condition $\left(\mathrm{K}=0.052\right.$ (days) $+0.001, \mathrm{R}^{2}=$ $0.046, \mathrm{df}=91, \mathrm{p}=0.04$ ) were all significant, although the relationship between number of days in the mesocosm and body condition was weak. Fish that spent more time in the mesocosm had greater increases in SL and in weight overall and these fish had faster growth rates per day (data not shown). Many individuals from all groups that spent at least 3 weeks in the mesocosm increased in SL, weight, and body condition, except for the two fish in group 4 (figs. 13-15). Of the suckers that spent at least 3 weeks in the mesocosm, few decreased in SL (7.9 percent; 10/127; fig. 13), weight (2.2 percent; 2/93; fig. 14) and body condition (15 percent, 14/93; fig. 15). Three fish had no change in SL. When compared to wild age- 0 juvenile suckers collected near the mesocosm in 2014 (average \pm SD, $9.08 \pm$ $4.13 \mathrm{mg} / \mathrm{g})$, mesocosm fish $(5.94 \pm 2.48 \mathrm{mg} / \mathrm{g})$ had significantly lower whole body triglyceride levels $(\mathrm{t}$ $=3.9, \mathrm{df}=22, \mathrm{p}<0.05)$. 


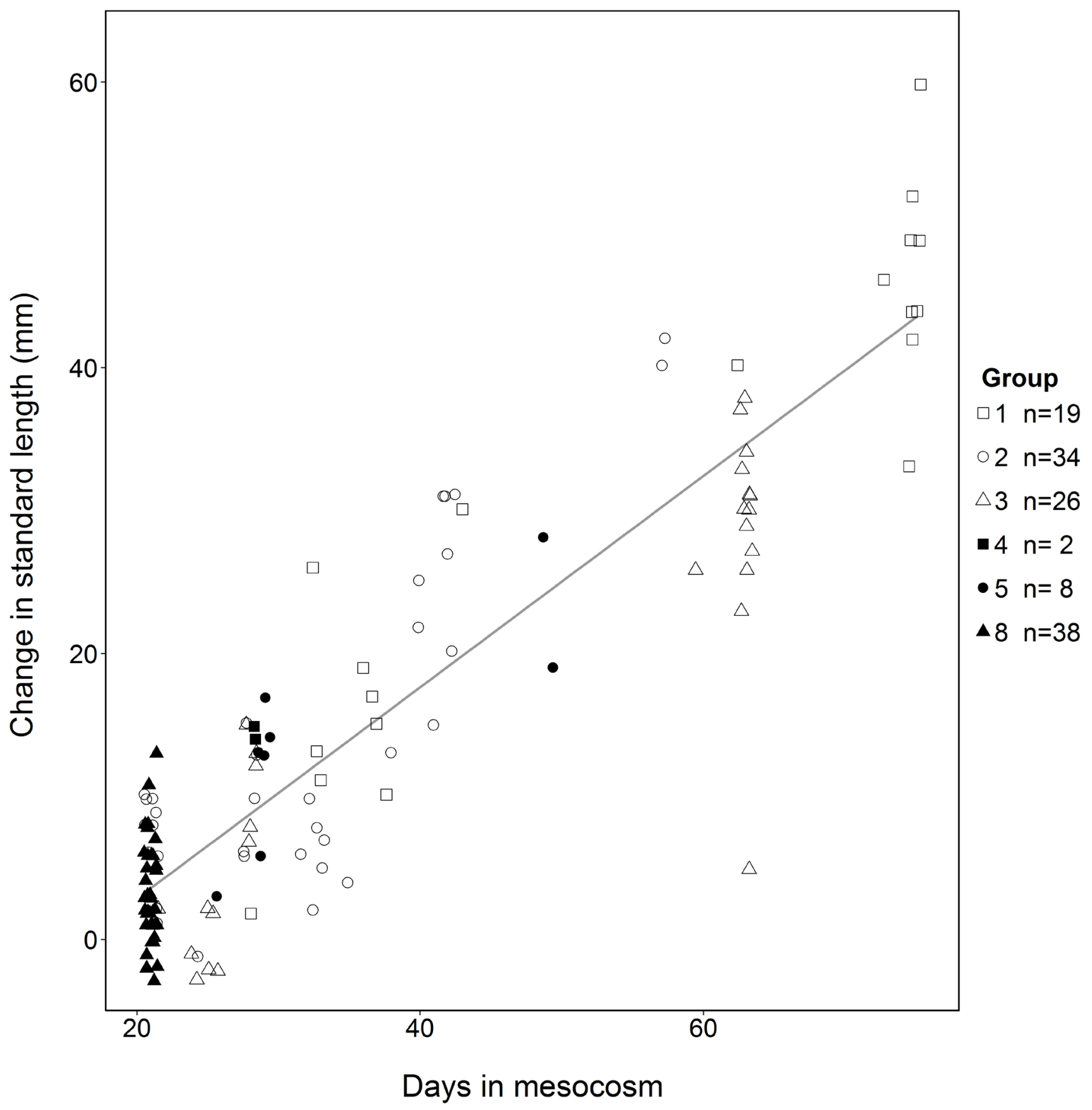

Figure 13. Change in standard length and total number of days in the mesocosm for juvenile Lost River suckers in Upper Klamath Lake, Oregon. Change in standard length $=0.74$ (days)-11.92 $\left(R^{2}=0.81,125 \mathrm{df}, \mathrm{p}<0.01\right)$. 


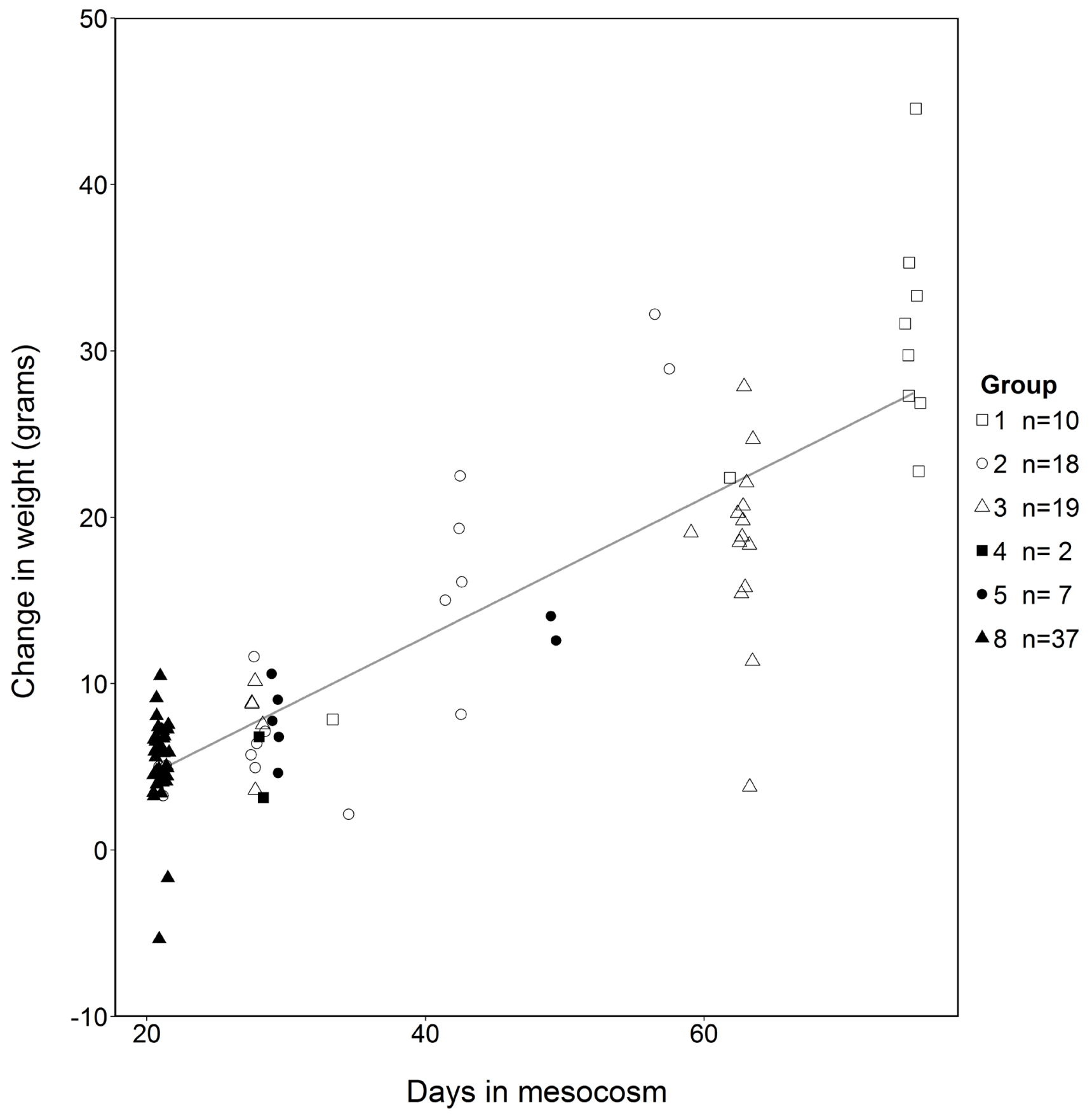

Figure 14. Change in weight and total number of days in the mesocosm for juvenile Lost River suckers in Upper Klamath Lake, Oregon. Change in weight $=0.42$ (days) $-3.95\left(R^{2}=0.757,91 \mathrm{df}, p<0.01\right)$. 


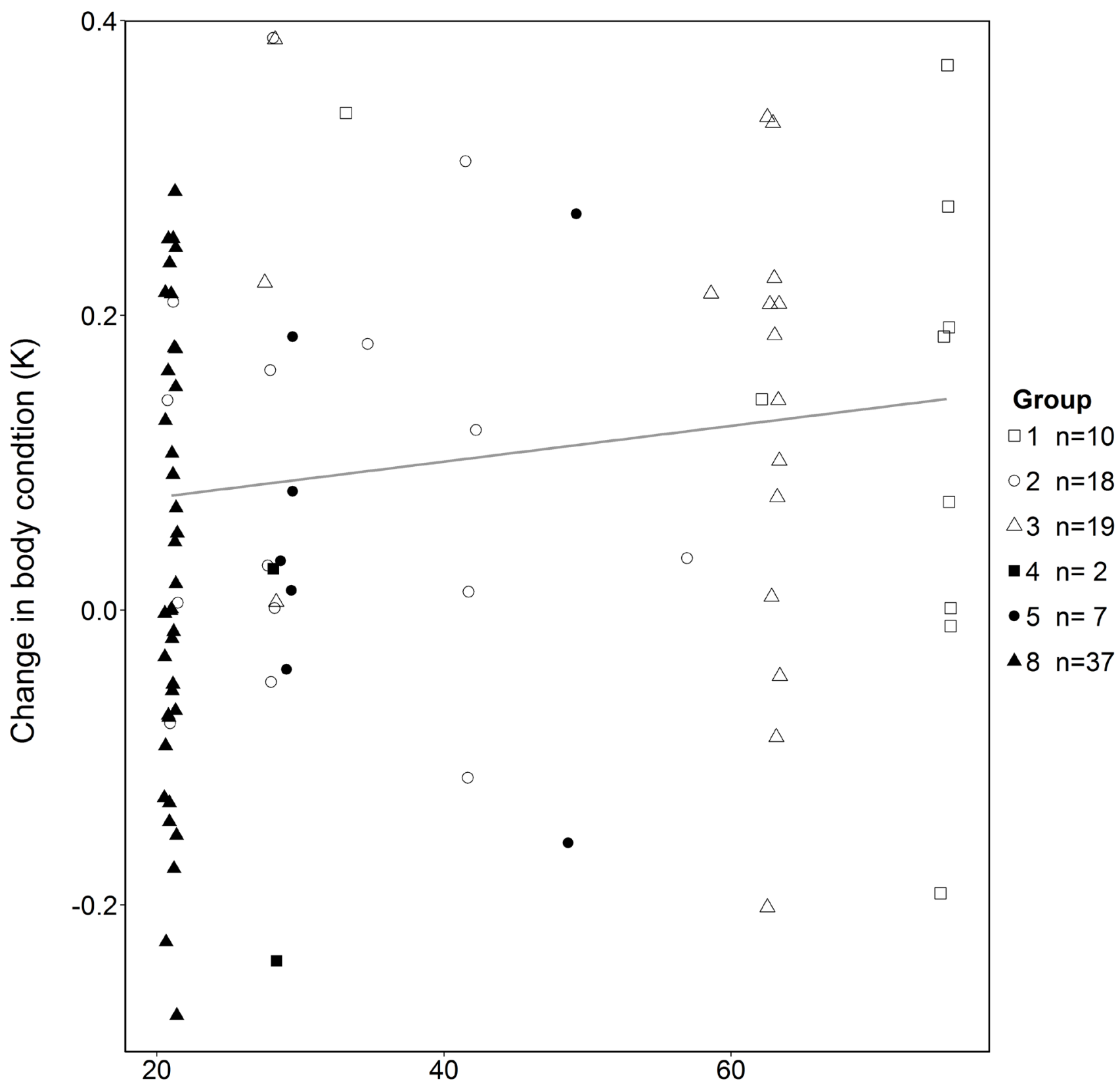

Days in mesocosm

Figure 15. Change in body condition $\left(K=\left(w t / S L^{3}\right)^{*} 10^{5}\right)$ and total number of days in the mesocosm for juvenile Lost River suckers in Upper Klamath Lake, Oregon. Change in body condition $=0.052$ (days) $+0.001\left(R^{2}=0.046,91\right.$ $\mathrm{df}, \mathrm{p}=0.04$ ). 
Suckers did not appear to starve within the mesocosm over the duration of the study.

Triglyceride concentrations ranged from 2.0 to $8.9 \mathrm{mg}$ of triglycerides per $\mathrm{g}$ of body tissue. The range in triglyceride concentrations was greater at the beginning of the study period than near the end (fig. 16). Qualitative examination of data did not reveal an increasing or decreasing trend in $\mathrm{mg}$ of triglycerides per $g$ of tissue over the duration of the study (fig. 16).

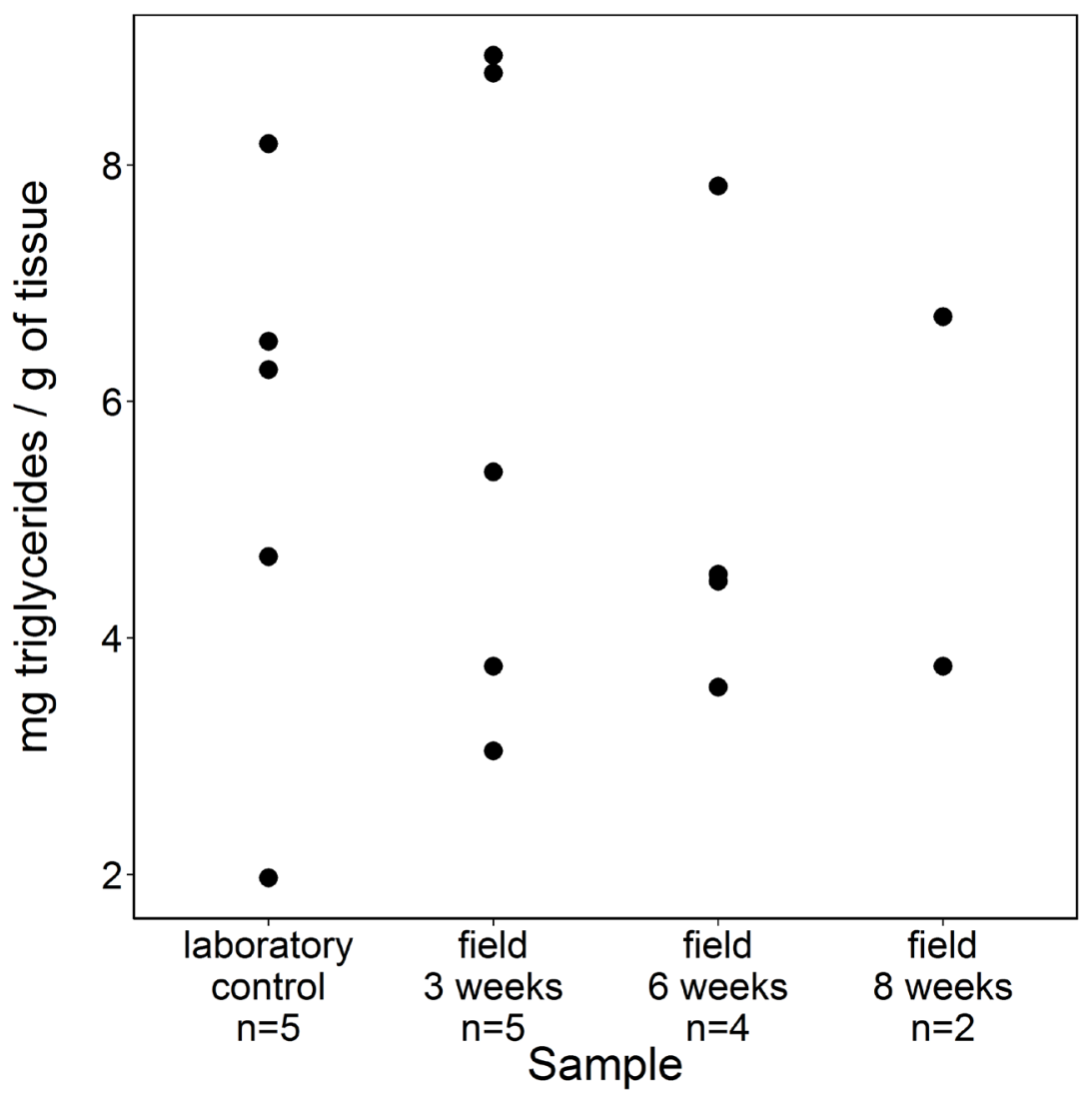

Figure 16. Whole fish triglyceride levels ( $\mathrm{mg} / \mathrm{g}$ of body tissue) of juvenile Lost River suckers sacrificed directly from the research facility, and at 3 (7-28-14), 6 (8-18-14), and 8 (9-2-14) weeks post introduction from group 2, Upper Klamath Lake, Oregon. 


\section{Necropsies}

The most common parasite found on suckers sacrificed from the mesocosm was Bolbophorus sp., also known as the black spot trematode (table 6). However, black spot was not found on any moribund fish. Lernaea sp. copepods were more common on moribund fish (7.1 percent) than sacrificed fish (3.1 percent), as were wounds associated with Lernaea sp. attachment. Petechial hemorrhaging was present in 57.1 percent of moribund fish and 14.1 percent of sacrificed fish. Presumed columnaris caused by the bacterium Flavobacterium columnare was present in 7.1 percent of moribund fish and in 2.1 percent of sacrificed fish. One sacrificed fish had exophthalmos (protruding eyeballs). Scale loss occurred in 1.0 percent of sacrificed fish and no moribund fish while fin damage was present in 2.6 percent of sacrificed fish and 14.3 percent of moribund fish.

Field necropsies identified visceral fat in amounts varying from none to high (table 7). Most gall bladders were yellow, some were light green, and few were dark green (table 7). All gall bladders were not full. Pale gills were observed in one moribund specimen, but no sacrificed specimens and all gills appeared normal (not clubbed, frayed, or marginate, and without other apparent lesions) in all field assessments. Liver color was most often dark red or pink, although there were a few instances of light brown livers (table 7). Most liver texture was smooth, although grainy textures also were observed. Spleen color was most often dark red or pink, although one moribund fish had a spleen that was light brown (table 7).

Table 6. Prevalence of parasites, bacterial disease, and other abnormalities for moribund $(n=14)$ and sacrificed, non-moribund $(n=192)$ Lost River suckers in the mesocosm in Upper Klamath Lake, Oregon.

[Moribund fish were collected July 29-September 11, 2014. Sacrificed fish were collected July 21-September 15, 2014]

\begin{tabular}{lcr|rr}
\hline \multirow{2}{*}{ Abnormality } & \multicolumn{2}{c|}{ Prevalence } & \multicolumn{2}{c}{ Percent occurrence } \\
\cline { 2 - 5 } & Moribund & Sacrificed & Moribund & Sacrificed \\
\hline $\begin{array}{l}\text { Parasites } \\
\quad \text { Black spot }\end{array}$ & - & 40 & - & 20.8 \\
$\quad \begin{array}{l}\text { Lernaea } \\
\text { Bacterial disease }\end{array}$ & 1 & 6 & 7.1 & 3.1 \\
$\quad \begin{array}{l}\text { Presumed columnaris } \\
\text { Other abnormalities }\end{array}$ & 1 & 4 & 7.1 & 2.1 \\
$\quad$ Fin damage & & & & \\
$\quad$ Scale loss & 2 & 5 & 14.3 & 2.6 \\
$\begin{array}{l}\text { Petechial hemorrhaging } \\
\text { Exopthalmos }\end{array}$ & - & 2 & - & 1.0 \\
& 8 & 27 & 57.1 & 14.1 \\
\hline
\end{tabular}


Table 7. Condition of tissues from necropsies performed in the field immediately following sacrifice for moribund $(\mathrm{n}$ $=14$ ) and sacrificed, non-moribund $(n=78)$ Lost River suckers in the mesocosm in Upper Klamath Lake, Oregon.

[Moribund fish were collected July 29-September 11, 2014. Sacrificed fish were collected July 21-September 15, 2014]

\begin{tabular}{|c|c|c|c|c|c|}
\hline \multirow{2}{*}{ Parameter } & & \multicolumn{2}{|c|}{ Prevalence } & \multicolumn{2}{|c|}{ Percent occurrence } \\
\hline & & Moribund & Sacrificed & Moribund & Sacrificed \\
\hline \multicolumn{6}{|l|}{ Visceral fat } \\
\hline & high & 4 & 17 & 28.6 & 21.8 \\
\hline & minimal & 5 & 34 & 35.7 & 43.6 \\
\hline & none & 5 & 27 & 35.7 & 34.6 \\
\hline \multicolumn{6}{|c|}{ Gall bladder condition } \\
\hline & partially full & 14 & 78 & 100.0 & 100.0 \\
\hline & full & - & - & - & - \\
\hline \multicolumn{6}{|l|}{ Gall bladder color } \\
\hline & yellow & 10 & 71 & 71.4 & 91.0 \\
\hline & light green & 3 & 6 & 21.4 & 7.7 \\
\hline & dark green & 1 & 1 & 7.1 & 1.3 \\
\hline \multicolumn{6}{|l|}{ Gill color } \\
\hline & normal & 13 & 78 & 92.9 & 100.0 \\
\hline & pale & 1 & - & 7.1 & - \\
\hline \multicolumn{6}{|l|}{ Gill condition } \\
\hline & clubbed & - & - & $\begin{array}{c}100.0 \\
-\end{array}$ & $\begin{array}{c}100.0 \\
-\end{array}$ \\
\hline & marginate & - & - & - & - \\
\hline & lesions & - & - & - & - \\
\hline & frayed & - & - & - & - \\
\hline \multicolumn{6}{|l|}{ Liver color } \\
\hline & dark red & 10 & 44 & 71.4 & 56.4 \\
\hline & pink & 3 & 30 & 21.4 & 38.5 \\
\hline & light brown & 1 & 3 & 7.1 & 3.8 \\
\hline & not found & 1 & 1 & 7.1 & 1.3 \\
\hline \multicolumn{6}{|l|}{ Liver texture } \\
\hline & smooth & 10 & 56 & 71.4 & 71.8 \\
\hline & grainy & 4 & 21 & 28.6 & 26.9 \\
\hline & nodular & - & - & - & - \\
\hline & not found & 1 & 1 & 7.1 & 1.3 \\
\hline \multicolumn{6}{|l|}{ Spleen color } \\
\hline & $\begin{array}{l}\text { dark red } \\
\text { pink }\end{array}$ & $\begin{array}{r}12 \\
1\end{array}$ & $\begin{array}{l}46 \\
32\end{array}$ & $\begin{array}{r}85.1 \\
7.1\end{array}$ & $\begin{array}{l}59.0 \\
41.0\end{array}$ \\
\hline & light brown & 1 & - & 7.1 & - \\
\hline
\end{tabular}




\section{Histopathological Evaluation}

Histopathological evaluations were prioritized for 14 moribund suckers collected throughout the mesocosm study and for 19 non-moribund suckers collected from the mesocosm on August 4 or August 11,2014 , during a mortality event. Infestations of the flagellated protozoan ectoparasite Ichthyobodo sp. (formerly Costia) were found on the gills of 85.7 percent of the moribund fish and were associated with diffuse, severe lamellar epithelial hyperplasia and hypertrophy in most of the affected fish (table 8, figs. 17 and 18). The epithelial hyperplasia frequently resulted in fusion of the lamellae and formation of interlamellar cavities containing mucus and cellular debris. Gill epithelial cell hypertrophy also was commonly observed in moribund fish, whereas inflammation and necrosis of gill tissues were less consistently seen. Focal, mild to moderate inflammation also was observed in gills of 21 percent of the moribund fish. In contrast, Ichthyobodo sp. infestations were observed in only 15.8 percent of sacrificed non-moribund fish collected from the mesocosm during the mortality event (table 8). Ichthyobodo sp. numbers exceeded 50 parasites per microscope field in all infected fish. Moderate, focal lamellar inflammation and necrosis were observed in one non-moribund fish that was not infested with Ichthyobodo sp. parasites (table 8).

A large focus of severe inflammation and necrosis was present in the interpancreatic connective tissue of a single moribund fish (table 9), but no parasites were observed in this section. A single moribund fish had areas of mild, multifocal granulomatous inflammation indicative of chronic inflammation in the posterior kidney interstitium (table 9). Unencysted (presumably adult) digenean (trematode) parasites were observed in the gastrointestinal lumen of 28.6 percent of moribund fish but did not elicit a visible host response.

Other histopathological findings from moribund fish included focal liver inflammation (42.9 percent), which appeared as infiltration of inflammatory cells around blood vessels and bile ducts (perivascular and peribiliary cuffing) (table 9). Mild peribiliary and perivascular cuffing also was observed in 47.4 percent of sacrificed, non-moribund suckers (table 9). Of these, focal liver inflammation was more prevalent in non-moribund suckers sacrificed August 4 (77.8 percent) than nonmoribund suckers sacrificed August 11, 2014 (20.0 percent), when microcystin concentrations were higher. Increases in concentrated particulate microcystin were first detected August 6, 2014, but the peak concentration did not occur until August 20, 2014 (fig. 6). Mild to moderate, focal inflammation was observed in the liver parenchyma of 21.4 percent of moribund fish and mild, focal areas of inflammatory cells were present in 26.3 percent of non-moribund fish. No abnormalities were observed microscopically in the subsample of skin and muscle sections examined from four moribund and three sacrificed fish.

No hepatocyte glycogen was present in the livers of the majority of moribund fish (table 10). These fish also were heavily infested with Ichthyobodo sp. parasites. Microscopic evaluation of Ichthyobodo sp. infestation correlated with macroscopic observations of visceral fat made during sampling in that fat was not present or was minimal in all infested fish, whereas fat was scored as high in the fish where no parasites were observed microscopically. The livers of 78.6 percent of nonmoribund fish contained detectable glycogen in variable amounts (table 10). Macroscopic observations of visceral fat ranged from not present to high in non-moribund fish and correlated with microscopic findings of Ichthyobodo sp. parasites in most cases. 


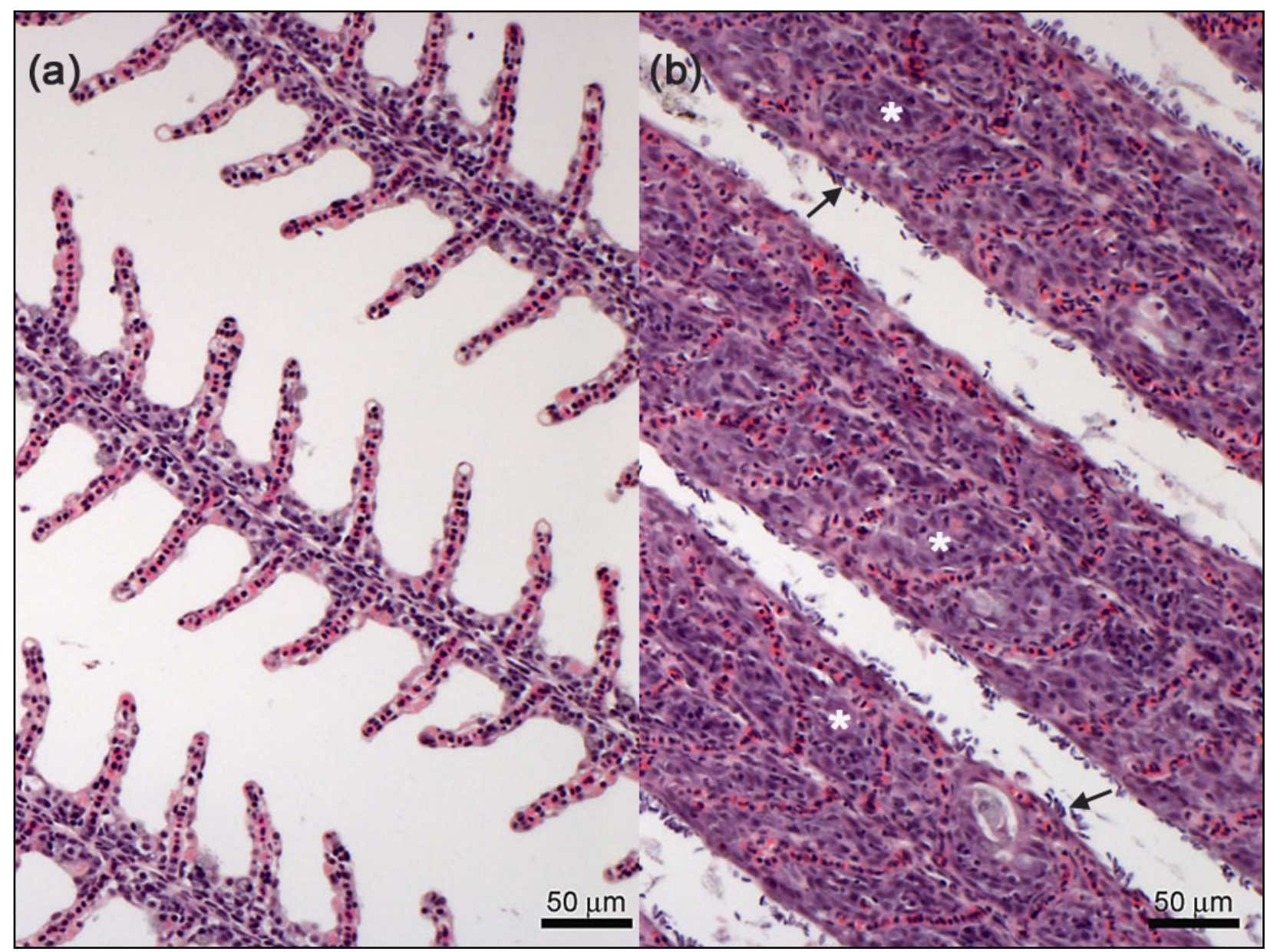

Figure 17. Gill lamellae from moribund Lost River suckers sampled from the mesocosm in Upper Klamath Lake. (a) Lamellae without Ichthyobodo sp. infestation. (b) Lamellae showing Ichthyobodo sp. parasites (arrows) and extensive epithelial hyperplasia with fusion of lamellae (asterisks). Hematoxylin and eosin stain. 


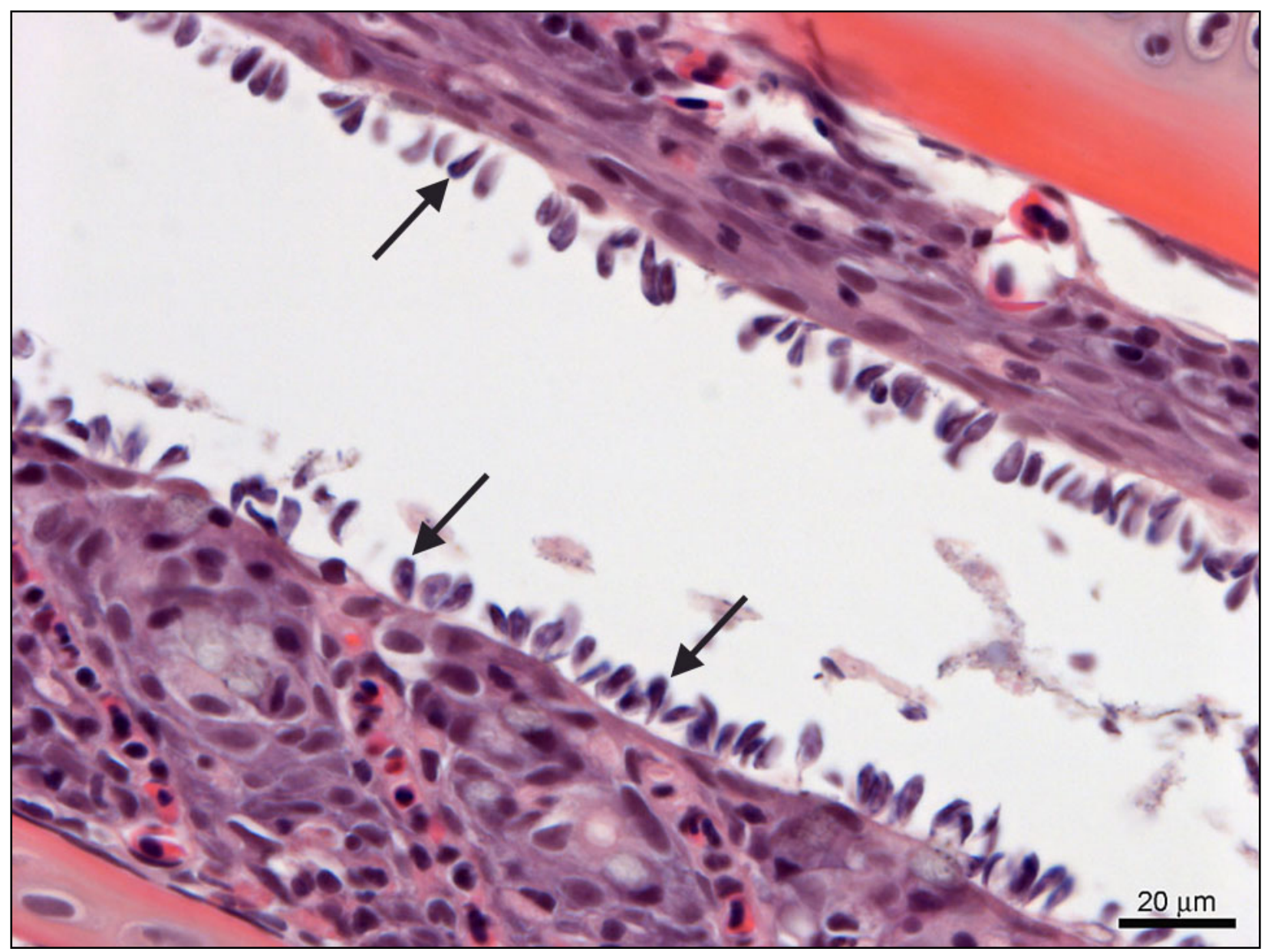

Figure 18. Ichthyobodo sp. parasites (arrows) attached to the gill lamellar epithelium. Hematoxylin and eosin stain. 
Table 8. Prevalence and percent occurrence of inflammation, necrosis, other histopathological changes, and parasites in gill tissue of Lost River suckers from the mesocosm in Upper Klamath Lake, Oregon.

[Moribund fish $(\mathrm{n}=14)$ were collected July 29-September 11, 2014. Sacrificed, non-moribund fish $(\mathrm{n}=19)$ were collected on August 4 or August 11, 2014]

\begin{tabular}{llcc|cc}
\hline \multirow{2}{*}{ Condition and parasites } & \multicolumn{2}{c|}{ Prevalence } & \multicolumn{2}{c}{ Percent occurrence } \\
\cline { 3 - 6 } & & Moribund & Sacrificed & Moribund & Sacrificed \\
\hline Condition & & & & \\
& Inflammation & 3 & 2 & 21.4 & 10.5 \\
& Necrosis & 1 & 1 & 7.1 & 5.3 \\
& Hyperplasia & 14 & 3 & 100 & 15.8 \\
\multirow{5}{*}{ Parasites } & Hypertrophy & 12 & 3 & 85.7 & 15.8 \\
& & & & & \\
& Ichthyobodo sp. & 12 & 3 & 85.7 & 15.8 \\
\hline
\end{tabular}

Table 9. Prevalence and percent occurrence of inflammation and necrosis in tissues of Lost River suckers from the mesocosm in Upper Klamath Lake, Oregon.

[Renal kidney and spleen tissue response were not observed in any fish. Gill response is shown in table 8 . Moribund fish ( $\mathrm{n}=$ 14) were collected July 29-September 11, 2014. Sacrificed, non-moribund fish $(\mathrm{n}=19)$ were collected on August 4 or August 11, 2014]

\begin{tabular}{lcc|cc}
\hline \multicolumn{1}{c}{ Condition } & \multicolumn{2}{c|}{ Prevalence } & \multicolumn{2}{c}{ Percent occurrence } \\
\cline { 2 - 5 } & Moribund & Sacrificed & Moribund & Sacrificed \\
\hline Hematopoietic kidney & 1 & - & 7.1 & - \\
$\quad$ Inflammation & & & & \\
$\quad$ Liver & & & & \\
$\quad$ Inflammation & 6 & 9 & 42.9 & 47.4 \\
$\quad \begin{array}{l}\text { Peribiliary/perivascular } \\
\quad \text { Parenchyma }\end{array}$ & 3 & 5 & 21.4 & 26.3 \\
$\quad$ Interpancreatic connective tissue & & & & \\
$\quad$ Inflammation & 1 & - & 7.1 & - \\
$\quad$ Necrosis & 1 & - & 7.1 & - \\
\hline
\end{tabular}

Table 10. Hepatocellular glycogen distribution evaluated by periodic acid-Schiff (PAS) and PAS-diastase staining in Lost River suckers from the mesocosm in Upper Klamath Lake, Oregon.

[Moribund fish $(\mathrm{n}=14)$ were collected July 29-September 11, 2014. Sacrificed, non-moribund fish $(\mathrm{n}=19)$ were collected on August 4 or August 11,2014]

\begin{tabular}{lcr|cr}
\hline \multicolumn{1}{c}{ Heptocellular } & \multicolumn{2}{c|}{ Prevalence } & \multicolumn{2}{c}{ Percent occurrence } \\
\cline { 2 - 5 } glycogen & Moribund & Sacrificed & Moribund & Sacrificed \\
\hline Multifocal-diffuse & - & 6 & - & 31.6 \\
Focal & 3 & 9 & 21.4 & 47.4 \\
None & 11 & 4 & 78.6 & 21.1 \\
\hline
\end{tabular}




\section{Discussion}

This study demonstrates that a mesocosm can be an effective tool to study juvenile Lost River sucker survival, vertical movement, and health in relation to water-quality conditions in Upper Klamath Lake. By use of a mesocosm, we were able to detect hourly mortality and model daily survival. We also were able to examine causes of mortality through correlation, necropsy, and histology. Additionally, we were able to describe vertical movement relative to vertically stratified water-quality conditions and assess change in individual growth, weight gain, and changes in body condition.

The observed high mortality during August in the mesocosm was consistent with late summer reductions in catch rates for wild suckers. Reductions in age- 0 sucker catch rates that occur from late July to mid-September nearly every year are thought to be due to high mortality (Burdick and others, 2009; Bottcher and Burdick, 2010). However, it has not been possible to estimate survival of wild juvenile Lost River suckers in Upper Klamath Lake due to low recapture rates and high levels of mortality (Burdick, 2013). The design of the present study allowed us to directly monitor mortality of hatchery-raised juvenile Lost River suckers in a mesocosm in Upper Klamath Lake.

The severity of the Ichthyobodo sp. gill infestations combined with the severity of the host tissue response suggested that ichthyobodiasis would likely have been the immediate cause of death of most of the sampled moribund fish in the mesocosm, although other infectious diseases, such as columnaris, and non-infectious factors, such as water quality, may have contributed to morbidity and mortality. The flagellated protozoan Ichthyobodo sp. is considered an obligate parasite that attaches to skin and gills, and in salmonids can be especially pathogenic to young fish or debilitated older fish (Lom and Dyková, 1992). The cause of death is believed to be parasitic destruction of surface cells with associated osmoregulatory breakdown, hemodilation and circulatory failure (Lom and Dyková, 1992), and the pathological changes in gill tissue likely also decrease respiratory function. Ichthyobodo sp. is geographically widespread and probably occurs in Upper Klamath Lake fish. However, Ichthyobodo sp. was not observed in any wild suckers caught in Upper Klamath Lake (Burdick and others, 2015). It is unknown whether the hatchery fish used to populate the mesocosm were infected with the parasite before they were introduced into the mesocosm because they were not examined microscopically prior to introduction. Future studies will screen hatchery-raised fish for parasites prior to introducing them to a mesocosm.

Mortality of suckers in the mesocosm varied relative to group and time but not water quality. Simpler group and time trend models, models including only groups or time trends, or models accounting for daily water-quality values failed to describe variation in survival better than the interactive model with group and quadratic time trends. Furthermore, water-quality conditions were not extreme enough for long periods to induce a response. Temporal and spatial distribution of wild juvenile suckers in Upper Klamath Lake has long been expected to coincide with changes in water-quality conditions; however, low capture rates have made testing this hypothesis difficult (Burdick and others, 2009; Burdick and VanderKooi, 2010). Although it is expected that wild fish avoid high temperatures and low DO, this study did not find a relationship between survival and changes in temperature or DO concentrations, perhaps because water-quality conditions were relatively benign in the study area. In general, the majority of mortality occurred during 3 weeks, and did not occur randomly throughout the season. Future studies using mesocosms will benefit from the insights gained during this study with improved study designs. For example, introducing all fish at once will reduce the noise associated with groups. Moreover, when mortalities first occur, more intensive sampling should coincide. For example, visual surveys for moribund fish are non-invasive (they do not disrupt all fish in the mesocosm) and may provide clues about causes of mortality. 
Although water-quality conditions recorded were not directly correlated with the mortality of suckers in the mesocosm, most water-quality conditions in or near the mesocosm in 2014 were more mild (higher DO concentrations, lower $\mathrm{pH}$, lower temperature, and lower un-ionized ammonia concentrations) than in other parts of the lake, although microcystin concentrations were higher than most other sampled locations in 2014 (Sara C. Eldridge, U.S. Geological Survey, written commun., 2015). Water-quality conditions have not been monitored annually at Fish Banks; however, general water-quality trends and patterns at other stations in Upper Klamath Lake were similar to those documented in the last decade (Kannarr and others, 2010; Eldridge and others, 2012a, 2013). Therefore, we think the water-quality conditions observed in 2014 are relatively typical of Fish Banks. In 2014, a small Aphanizomen flos-aquae crash occurred in mid-July in some parts of the lake (including at the mid-north site located $5.21 \mathrm{~km}$ from the mesocosm) and the major A. flos-aquae crash occurred in midAugust (Sara Eldridge, U.S. Geological Survey, oral commun., 2014). The major crash was followed by the highest documented microcystin concentrations in Upper Klamath Lake since measurements began in 2007 (Eldridge and others, 2012b; Sara Eldridge, U.S. Geological Survey, written commun., 2015). Microcystin concentrations were exceptionally high near the mesocosm on August 20, 2014 (43.2 $\mu \mathrm{g} / \mathrm{L}$, fig. 6) and at the mid-trench site (MDT) on September 9, $2014(51.9 \mu \mathrm{g} / \mathrm{L}$; Sara Eldridge, U.S.

Geological Survey, written commun., 2015). However, microcystin increased after the mortality event, so microcystin is not suspected as being the cause of mortality for suckers in the mesocosm.

Water temperature in the mesocosm did not exceed lethal levels and was not elevated for a sufficient time to cause mortality. Water temperature in the mesocosm never exceeded $30.5^{\circ} \mathrm{C}$, the 96 hour median limit $\left(\mathrm{LC}_{50}\right)$ for juvenile (0.48-0.86 $\mathrm{g}$ ) Lost River suckers (Saiki and others, 1999). However, the lethal temperature for larger bodied juvenile suckers (7.6-72.9 g, the range in this study) is not known. Larger bodied fish generally are more sensitive to high temperatures than smaller bodied fish (Roze and others, 2013), so it is possible that temperatures in the mesocosm were extreme enough to cause mortality of some individuals. Water temperatures in the mesocosm were greater than $27^{\circ} \mathrm{C}$ several times between July 9 and July 19, although temperatures were never greater than $28^{\circ} \mathrm{C}$ for more than 4 consecutive hours and only two mortalities occurred during this time. However, high temperatures are not likely to be the main cause of mortality because temperature was relatively benign during the mortality event July 28 -August $16\left(22.5 \pm 1.7^{\circ} \mathrm{C}\right.$, range $\left.=17.9-27.01\right)$. Water temperatures greater than $27^{\circ} \mathrm{C}$ are rare in Upper Klamath Lake (Terwilliger and others, 2003; Kannarr, 2010; Eldridge and others, 2012a), but poor apparent juvenile survival is widespread (Burdick and VanderKooi, 2010). Water temperatures may be one of many stressors that contribute to juvenile sucker mortality, however, this study was not able to associate temperature with the observed mortality.

It is unlikely that low DO concentrations were the direct cause of mortality of fish in the mesocosm because DO concentrations in the mesocosm were rarely less than $1.58 \mathrm{mg} / \mathrm{L}$, the 24 -hour median lethal concentration $\left(\mathrm{LC}_{50}\right)$ for juvenile $(0.39-0.86 \mathrm{~g})$ Lost River suckers (Saiki and others, 1999). Concentrations less than $1.58 \mathrm{mg} / \mathrm{L}$ never persisted in the mesocosm for more than 6 hours. Within the species, larger juvenile Lost River suckers have higher tolerances to low concentrations of DO (Meyer and Hansen, 2002). For example, late-stage juveniles (1.7-7.3 g) have lethal concentration tolerances of less than $1.4 \mathrm{mg} / \mathrm{L}$ over 24 hours and do not experience changes in swimming performance at DO concentrations of $2.1 \mathrm{mg} / \mathrm{L}$ over 14 days (Meyer and Hansen, 2002). The suckers used in our study were all greater than $7.5 \mathrm{~g}$ so it is not surprising that mortality did not occur when DO concentrations were extremely low for short periods of time. While DO conditions were never extreme at this site, it is possible that low DO concentrations had sub-lethal effects that contributed to the observed mortality. 
It is unlikely that high $\mathrm{pH}$ directly caused mortality of fish in the mesocosm because $\mathrm{pH}$ did not exceed 9.75. Lost River suckers have a high tolerance to elevated $\mathrm{pH}$; for short exposures (less than or equal to 48 hours), the mean lethal $\mathrm{pH}$ for juvenile suckers $(0.28-0.49 \mathrm{~g})$ is 10.66 (Saiki and others, 1999). For many species of fish, body size is an important component in $\mathrm{pH}$ tolerance; larger bodied fish have greater tolerances to high $\mathrm{pH}$ (Scott and Wilson, 2007). If this relationship holds true for all sizes of Lost River suckers, we would expect lethal $\mathrm{pH}$ levels to be higher for suckers in the mesocosm (mean weight $=25.2 \pm 17.3 \mathrm{~g}$, range $=7.6$ to $72.9 \mathrm{~g}$ ). Alkaline environments can cause mortality in fishes by inhibiting ion regulation and increasing internal un-ionized ammonia levels (Wilkie and Wood, 1996; Scott and Wilson, 2007). High pH does not appear to be associated with the mortality observed in this study.

Concentrations of un-ionized ammonia capable of causing mortality or structural changes to gills were never measured at Fish Banks, although they were recorded elsewhere in Upper Klamath Lake. The highest measured level of un-ionized ammonia $\left(103 \mu \mathrm{g} / \mathrm{L} \mathrm{NH}_{3}\right)$ was seven times below the 96-hour lethal concentration for juvenile $(0.49-0.80 \mathrm{~g})$ Lost River suckers $\left(\mathrm{LC}_{50}=780 \mu \mathrm{g} / \mathrm{L}\right.$, Saiki and others, 1999), and three times below concentrations known to cause structural gill changes (Lease and others, 2003). Concentrations of $370 \mu \mathrm{g} / \mathrm{L}$ result in increased diffusion distance, and increased thickness of the secondary lamellae of gills of Lost River suckers (Lease and others, 2003). Un-ionized ammonia concentrations exhibit spatial variation throughout Upper Klamath Lake; concentrations were higher than we report at the Mid-North Lower site on July 21, 2014; $603 \mu \mathrm{g} / \mathrm{L}$ (S.L.C. Eldridge, U.S. Geological Survey, unpub. data, 2014). Our sampling was likely representative of minor diel variation that may have occurred at Fish Banks (Liam Schenk, U.S. Geological Survey, written commun., 2014).

Despite very high microcystin concentrations in particulate samples, this toxin did not appear to be a primary cause of mortality of suckers in the mesocosm because high microcystin concentrations did not coincide with periods of high sucker mortality in the mesocosm. Sucker mortalities began to increase around July 28, whereas particulate fraction microcystin concentrations began to increase on August 6 . By the time microcystin concentrations peaked at $40.42 \mu \mathrm{g} / \mathrm{L}$ in the particulate fraction and increased above $1 \mu \mathrm{g} / \mathrm{L}$ in the dissolved fraction $(4.55 \mathrm{ug} / \mathrm{L}$ ) on August 20, 2014, most sucker mortality had already occurred. It is possible that microcystin exposure caused sublethal changes in tissues of suckers in the mesocosm. For example, perivascular cuffing in the liver, observed in some fish sampled from the mesocosm, is one of the clinical signs noted in net-pen disease of Atlantic salmon (Salmo salar), which is thought to be associated with microcystin exposure (Kent and others, 1996). However, perivascular/peribiliary cuffing represents an inflammatory immune response that can have a variety of causes, and is generally not considered an indicator of a specific etiology (Lang and others, 2006). Because the majority of fish in which perivascular/peribiliary was observed were sampled before microcystin concentrations began to increase, it is likely that the liver inflammation in most fish was caused by some other stressor. Peribiliary and/or perivascular cuffing also has been observed in wild suckers examined from Clear Lake Reservoir, California, where no microcystin was detected (Burdick and others, 2015).

Future studies using mesocosms should investigate how mortality varies across a spectrum of water-quality conditions. For example, if poor water quality is causing mortality, mesocosms located in areas with poor water quality could provide more clear relationships between water-quality parameters and mortality. Alternatively, if fish in mesocosms with generally poor water-quality conditions have similar rates of mortality as fish in mesocosms with good water quality, the "poor water quality" hypothesis as a cause of mortality for hatchery raised fish in a mesocosm could be eliminated. 
Many factors or unmeasured parameters could account for the observed variation in survival among groups. For example, transport time or transport conditions, such as temperature or DO concentrations in the cooler, or stress induced from lake turbulence on the boat, could be stress related covariates that may explain why some groups had lower survival than others. Unmeasured stressors associated with time spent at the research facility could also explain why some groups had lower survival than others. For example, if Ichthyobodo sp. originated from the research facility, levels of infestation could have varied throughout the summer and affected some groups more than others. Treating fish with formalin or an antibiotic prior to introduction into the mesocosm could control for some variation associated with time spent at the research facility. However, the best way to control for variation associated with groups is to eliminate staggered entry in future mesocosm studies and introduce all fish at the beginning of the study.

Vertical movements were predictable throughout the summer and were associated with darkness more than any measured water-quality parameter. One explanation for the lack of movement response to water quality may be that the differences in temperature, DO concentrations, and $\mathrm{pH}$ between Surface and Benthos were minor and surfacing in most instances would provide little relief. When DO concentrations were extremely low near the benthos, suckers did not move up into the water column where DO concentrations were much higher. Instead, low DO concentrations observed on July 15 appeared to reduce sucker activity. Typically suckers spent dark hours (2100-0400) using the entire water column, but on July 15, suckers stayed near the benthos where DO concentrations were very low. A wide variety of behavioral responses have been associated with hypoxic conditions. For example, long hypoxic exposures reduced swimming behavior in cod (Gadus morhua), while short-term hypoxic conditions increased activity (Herbert and Steffensen, 2005; Chabot and Claireaux, 2008). Long-term exposure to hypoxic conditions caused cod to conserve energy for metabolic processes while short-term exposures induced an avoidance response (Herbert and Steffensen, 2005; Chabot and Claireaux, 2008). Reduced activity level could be an adaptive strategy to conserve energy when conditions are harsh. Certain other hypoxia-tolerant cypriniform fish species, such as the common carp Cyprinus carpio (Zhou and others, 2000) and crucian carp Carassius carassius (Nilsson and Renshaw, 2004), exhibit reduced activity during prolonged hypoxia. In contrast, adult Lost River suckers have been observed moving into areas with better water quality during extreme low DO events to seek refuge (Banish and others, 2009). Juvenile suckers also may move spatially to escape low DO concentrations if they are not contained (as they were in the mesocosm) or they may surface to gulp air and acquire oxygen, as observed by Foott and others (2007).

While typically considered a benthic species, Lost River suckers are thought to be partially pelagic based on their diet, mouth morphology, and gill raker structure (Tranah and May, 2006). The diets of larvae originate from the surface, but become predominantly benthic as suckers develop into juveniles (Markle and Clauson, 2006). The diet of juvenile suckers in Upper Klamath Lake consists primarily of "goop" (thought to have benthic origins) and benthic chironomids and crustaceans, although diets also include some planktonic food items, such as Daphnia and copepods (Markle and Clauson, 2006). Vertical movements are common in fishes and are usually associated with foraging behavior and predator avoidance (Henderson and Fabrizio, 2014). It is possible that juvenile suckers move vertically into the water column to take advantage of additional food resources during times of reduced avian predation (at night). However, at least two avian predators, American White Pelicans (Pelecanus erythrorhynchos) and Double-crested Cormorants (Phalacrocorax auritus), have been known to nocturnally forage; although nocturnal foraging is rare for Double-crested Cormorants (McMahon and Evans, 1992; King and others, 1998). Nocturnal foraging has not been specifically studied for these species in Upper Klamath Lake, although both species are known predators of juvenile 
suckers (Burdick, 2012). If vertical movement is typical of wild juvenile suckers, it likely represents a tradeoff between eating and being eaten. However, this behavior could be an artifact of the artificial environment in the mesocosm. Suckers had limited access to the benthos, and may have resorted to riskier foraging behavior. Finally, the observed behavior could be due to the juvenile suckers being hatchery-raised and potentially naïve to predators. Bird netting prevented avian predation within the mesocosm.

The density of fish in the mesocosm did not appear to prevent fish growth or decrease condition, although we were unable to directly assess how density affects condition with only one mesocosm. Maintenance of body condition suggested that juvenile suckers in the mesocosm were not resource limited (Encina and Grando-Lorencio, 1997). Overall increases in SL and weight suggested that most fish were able to grow in the mesocosm. Whole body triglycerides did not appear to decrease over time, which suggested that these suckers did not lose fat in the mesocosm. Increases in size but relatively constant triglyceride levels may suggest that fish in the mesocosm were allocating more energy to somatic growth than energy storage over the summer. How fish allocate limited resources directly affects their survival and fitness, and if essential resources are limited, fish will be unable to increase body weight or length (Post and Parkinson, 2001). Larger sample sizes, especially for triglyceride analysis could better assess this hypothesis.

Temporal changes in triglyceride levels were similar to what is observed in wild fish. Whole body triglyceride levels of wild age- 0 juvenile suckers collected near the mesocosm were on average higher than our samples of age-1 fish. However, similar to our samples, wild fish triglyceride levels were relatively constant from July 10 to September 11, 2014 (Burdick and others, 2015). In comparison to wild out-migrant age-0 suckers captured in the Link River between mid-July and early September 2009 (6-11 mg/g), our age-1 research-facility and mesocosm juveniles $(2.0-8.9 \mathrm{mg} / \mathrm{g})$ had less whole body triglycerides, though the observed differences could be due to many factors including differences in age, year, season, environmental conditions, and rearing conditions (Foott and others, 2012). Seasonal fluctuations in lipid storage are poorly understood for many wild fish populations (Næsje and others, 2006) including Lost River suckers. Temperate fishes that live in seasonal environments typically experience net lipid gains during summer growing months and decreases during winter months (Post and Parkinson, 2001); however, changes in seasonal lipid biomass varies by species. Fat storage typically occurs when resources are abundant to prevent mortality when energy demands are high or resources are scarce (Næsje and others, 2006). Poor water-quality conditions in the summer in Upper Klamath Lake are expected to be stressful for suckers (U.S. Fish and Wildlife Service, 2013), so it is not surprising that we did not observe increases in triglycerides over the summer season. Large sample sizes and studies directed at investigating year round seasonal changes in wild juvenile sucker growth, body condition, and whole body triglycerides would be helpful for interpreting the trends observed in this study.

Liver and muscle glycogen are major energy reserves in fish, and liver glycogen is an important glucose energy source that enables hypoxia-tolerant fishes, such as common carp and crucian carp, to survive periods of oxygen depletion (Zhou and others, 2000; Nilsson and Renshaw, 2004). Hepatocyte glycogen in the livers of most of the non-moribund fish examined from the mesocosm was present but in variable amounts. The amount of hepatocyte glycogen did not appear to be linked to the amount of time a sucker spent in the mesocosm, although there were insufficient data available to assess this relationship. The lack of hepatocellular glycogen (or lipid) observed microscopically in the Ichthyobodo sp. infested fish is not surprising, as fish affected with this parasite are often anorexic (Gratzek, 1993). 
Wild suckers collected from both Upper Klamath Lake and Clear Lake in 2014 showed decreases in hepatocellular glycogen by histological analysis in samples taken from early August through midSeptember (when sampling ceased), although the significance of that finding is unknown (Burdick and others, 2015). Exposure to microcystin in the diet can interrupt blood and hepatocyte glycogen regulation and result in depletion of glycogen storage (Malbrouck and Kestsmont, 2006; Acuna and others, 2012), but the decrease in hepatocellular glycogen in suckers from Clear Lake, where microcystin was not detected, suggests that this finding may be associated with other factors such as food availability in the lakes (Burdick and others, 2015). Field necropsy evaluations of the color and condition of various organs of fish, as was done in this study, provide a means of establishing a database for detecting trends in the health of a fish population over time (Adams and others, 1993). Changes in size, color, texture or shape of an organ may occur in response to pathogens, environmental contaminants, or other stressors, nutritional status, or feeding activity (Goede and Barton, 1990; Helfman and others, 2009). Information derived from these macroscopic evaluations of moribund and asymptomatic fish can provide a means of rapidly assessing general health of suckers in the field to complement other analyses.

Petechial hemorrhages on the skin were common among moribund fish but also occurred less frequently on some sacrificed fish. While often an indicator of infectious agents such as bacteria, abrasion also can cause petechial hemorrhages (Ferguson, 1989). Petechial hemorrhaging has been observed in wild juvenile suckers in Upper Klamath Lake but not in Clear Lake Reservoir where juvenile sucker survival is higher (Burdick and others, 2015).

This pilot study has effectively demonstrated that mesocosms can be a powerful tool for studying juvenile Lost River sucker movement, growth, health, and mortality. Vertically stratified antennas and PIT-tagged fish allowed us to analyze hourly movements and model daily mortality. Movement was not associated with vertically stratified water-quality conditions but was associated with diel daylight patterns. Most mortality occurred from July 28 to August 16 and was not directly related to water-quality conditions, although indirect effects may have occurred. Ichthyobodo sp. appears to be the primary cause of death for most moribund suckers, but the origin of this parasite is still unknown. Although the causation of juvenile mortality remains unclear, this study has demonstrated that this design can provide quantitative data to assess juvenile mortality.

\section{Acknowledgments}

Data for this project were collected with the help of USGS Klamath Falls Field Station staff Todd Perry, Brian Hayes, Justin Miles, Courtney Fujishin, Mark Johnson, and Mark Hereford. Barbara Martin (USGS) was instrumental in rearing and caring for the fish used in this project. Greta Blackwood provided technical support. Sara Eldridge (USGS) provided assistance with water-quality data. Scott Foott and Ron Stone (USFWS) propagated and raised the Lost River suckers used in this project. The Klamath Tribes Sprague River Fish Research Facility and Water Quality Laboratory provided crucial support hosting and caring for the fish used in this project. The Nature Conservancy provided winter storage for the dock. 


\section{References Cited}

Acuna, S., Baxa, D., Teh, S., 2012, Sublethal dietary effects of microcystin producing Microcystis on threadfin shad, Dorosoma petenese: Toxicon, v. 60, p. 1191-1202.

Adams, S.M., Brown, A.M., and Goede, R.W., 1993, A quantitative health assessment index for rapid evaluation of fish condition in the field: Transactions of the American Fisheries Society, v. 122, p. 63-73.

Banish, N.P., Adams, B.J., Shively, R.S., Mazur, M.M., Beauchamp, D.A., and Wood, T.M., 2009, Distribution and habitat associations of radio-tagged adult Lost River suckers and shortnose suckers in Upper Klamath Lake, Oregon: Transactions of the American Fisheries Society, v. 138, p. 153-168.

Bottcher, J.L., and Burdick, S.M., 2010, Temporal and spatial distribution of endangered juvenile Lost River and shortnose suckers in relation to environmental variables in Upper Klamath Lake, Oregon— 2009 annual data summary: U.S. Geological Survey Open-File Report 2010-1261, 42 p.

Bradbury, J.P., Colman, S.M., and Reynolds, R.L., 2004, The history of recent limnological changes and human impact on Upper Klamath Lake, Oregon: Journal of Paleolimnology, v. 31, p. 151-165.

Burdick, S.M., 2012, Tagging age-1 Lost River and shortnose suckers with passive integrated transponders, Upper Klamath Lake, Oregon-Summary of 2009-11 effort: U.S. Geological Survey Open-File Report 2012-1076, 10 p.

Burdick, S.M., 2013, Assessing movement and sources of mortality of juvenile catostomids using passive integrated transponder tags, Upper Klamath Lake, Oregon-Summary of 2012 effort: U.S. Geological Survey Open-File Report 2013-1062, 12 p.

Burdick, S.M., Elliott, D., Ostberg, C., Conway, C., Dolan-Caret, A., Hoy, M., Feltz, K., and Echols, K., 2015, Health and condition of endangered juvenile Lost River and shortnose suckers relative to Water Quality and Fish Communities in Upper Klamath Lake, Oregon and Clear Lake Reservoir, California: U.S. Geological Survey Open-File Report 2015-1217, 56 p. [Also available at http://dx.doi.org/10.3133/ofr20151217.]

Burdick, S.M., and Hewitt, D.A., 2012, Distribution and condition of young-of-year Lost River and shortnose suckers in the Williamson River Delta restoration project and Upper Klamath Lake, Oregon, 2008-10-Final Report: U.S. Geological Survey Open-file Report 2012-1098, 52 p.

Burdick, S.M., and VanderKooi, S.P., 2010, Temporal and spatial distribution of endangered juvenile Lost River and shortnose suckers in relation to environmental variables in Upper Klamath Lake, Oregon-2008 annual data summary: U.S. Geological Survey Open-File Report 2010-1051, 36 p.

Burdick, S.M., VanderKooi, S.P., and Anderson, G.O., 2009, Spring and summer spatial distribution of endangered juvenile Lost River and shortnose suckers in relation to environmental variables in Upper Klamath Lake, Oregon-2007 Annual Report: U.S. Geological Survey Open-File Report 2009-1043, 56 p.

Burnham, K.P., and Anderson, D.R., 2002, Model selection and multimodel inference-A practical information-theoretic approach (2nd ed.): Springer, New York, 488 p.

Carmichael, W.W., 1994, The toxins of cyanobacteria: Scientific American, v. 270, p. 78-86.

Carson, F.L., Martin, J.H., and Lynn, J.A., 1973, Formalin fixation for electron microscopy-A reevaluation: American Journal of Clinical Pathology, v. 59, p. 365-73.

Chabot, D., and Claireaux, G., 2008, Environmental hypoxia as a metabolic constraint on fish-The case of Atlantic cod, Gadus morhua: Marine Pollution Bulletin, v. 57, p. 287-294.

Devries, J.H., Citta, J.J., Lindberg, M.S., Howerter, D.W., and Anderson, M.G., 2003, Breeding-season survival of mallard females in the prairie pothole region of Canada: The Journal of Wildlife Management, v. 67, p. 551-563.

Eilers, J., Kann, J., Cornett, J., Moser, K., St. Amand, A., and Gubala, C., 2001, Recent paleolimnology of Upper Klamath Lake, Oregon: Rosenburg, Oregon, J.C. Headwaters, Inc., Prepared for U.S. Bureau of Reclamation, Klamath Falls, Oregon, 44 p. 
Eldridge, D.B., Eldridge, S.L.C., Schenk, L.N., Tanner, D.Q., and Wood, T.M., 2012a, Water-quality data from Upper Klamath and Agency Lakes, Oregon, 2009-10: U.S. Geological Survey Open-File Report 2012-1142, 32 p.

Eldridge, S.L.C., Wood, T.M., and Echols, K.R., 2012b, Spatial and temporal dynamics of cyanotoxins and their relation to other water quality variables in Upper Klamath Lake, Oregon, 2007-09: U.S. Geological Survey Scientific Investigations Report 2012-5069, 34 p.

Eldridge, S.L.C., Wood, T.M., Echols, K.R., and Topping, B.R, 2013, Microcystins, nutrient dynamics, and other environmental factors during blooms of non-microcystin-producing Aphanizomenon flos-aquae in Upper Klamath Lake, Oregon, 2009: Lake and Reservoir Management, v. 29, p. 68-81.

Ellsworth, C.M., and Martin, B.A., 2012, Patterns of larval sucker emigration from the Sprague and lower Williamson Rivers of the Upper Klamath Basin, Oregon, after the removal of Chiloquin Dam - 2009-10 Annual Report: U.S. Geological Survey Open-File Report 2012-1037, 34 p.

Ellsworth, C.M., Tyler, T.J., VanderKooi, S.P., and Markle, D.F., 2009, Patterns of larval sucker emigration from the Sprague and lower Williamson Rivers of the Upper Klamath Basin, Oregon, prior to the removal of Chiloquin Dam - 2006 annual report: U.S. Geological Survey Open-File Report 2009-1027, 32 p.

Encina, L., and Granado-Lorencio, C., 1997, Seasonal variations in the physiological status and energy content of somatic and reproductive tissues of chub: Journal of Fish Biology, v. 50, p. 511-522.

Fairchild, J.F., Allert, A.L., Sappington, L.C., and Waddell, B., 2005, Chronic toxicity of un-ionized ammonia to early life stages of endangered Colorado pikeminnow (Ptychocheilus lucius) and Razorback Sucker (Xyrauchen texanus) Compared to the Surrogate Fathead Minnow (Pimephales promelas): Archives of Environmental Contamination and Toxicology, v. 49, p. 378-384.

Falconer, I.R., 1999, An overview of problems caused by toxic blue-green algae (cyanobacteria) in drinking and recreational water: Environmental Toxicology, v. 14, p. 5-12.

Ferguson, H.W., 1989, Systemic pathology of fish: Ames, Iowa State University Press, 263 p.

Foott, J.S., Stone, R., and Forgerty, R., 2007, Lack of disease response in juvenile Upper Klamath Lake suckers (age 0+) to adverse water conditions- Pilot study August 2007: U.S. Fish \& Wildlife Service, Nevada Fish Health Center, 12 p.

Foott, J.S., Stone, R., Wilkens, A., and Rasmussen, J., 2012, Juvenile Lost River Sucker survival and energetics in Upper Klamath Lake mesocosm cages-July-December 2011: U.S. Fish and Wildlife Service California, Nevada Fish Health Center, 49 p., http://www.fws.gov/canvfhc/reports.asp.

Goede, R.W., and Barton, B.A., 1990, Organismic indices and an autopsy-based assessment as indicators of health and condition in fish: American Fisheries Society Symposium, v. 8, p. 93-108.

Gratzek, J.B., 1993, Parasites associated with freshwater tropical fishes, in Stoskopf, M.K., ed., W.B., Fish medicine: Philadelphia, Pennsylvania, Saunders Co., 882 p.

Helfman, G.S., Collette, B.B., Facey, D.E., and Bowen, B.W., 2009, Diversity of Fishes (2nd ed.): United Kingdom, John Wiley and Sons, Ltd., 720 p.

Herbert, N.A., and Steffensen, J.F., 2005, The response of Atlantic cod, Gadus morhua, to progressive hypoxia-Fish swimming speed and physiological stress: Marine Biology, v. 147, p. 1403-1412.

Hewitt, D.A., Janney, E.C., Hayes, B.S., and Harris, A.C., 2014, Demographics and run timing of adult Lost River (Deltistes luxatus) and shortnose (Chasmistes brevirostris) suckers in Upper Klamath Lake, Oregon, 2012: U.S. Geological Survey Open-File Report 2014-1186, 44 p. [Also available at http://dx.doi.org/10.3133/ofr20141186.]

Horne, A.J., and Goldman, C.R., 1994, Limnology (2nd ed): New York, McGraw-Hill, Inc., 576 p.

Kann, J., and Smith, V.H., 1999, Estimating the probability of exceeding elevated $\mathrm{pH}$ values critical to fish populations in a hypereutrophic lake: Canadian Journal of Fisheries and Aquatic Science, v. 56, p. 22622270. 
Kannarr, K.E., Tanner, D.Q., Lindenberg, M.K., and Wood, T.M., 2010, Water-quality data from Upper Klamath and Agency Lakes, Oregon, 2007-08: U.S. Geological Survey Open-File Report 2010-1073, $28 \mathrm{p}$.

Kaplan, E.L., and Meier, P., 1958, Nonparametric estimation from incomplete observations: Journal of the American Statistics Association, v. 53, p. 457-481.

Kent, M.L., Dawe, S.C., St. Hilaire, S., and Andersen, R.J., 1996, Effects of feeding rate, seawater entry, and exposure to natural biota on the severity of net-pen liver disease among pen-reared Atlantic salmon: The Progressive Fish-Culturist, v. 58, p. 43-46.

King, D.T., Barrel, J.B., Dorr, B., and Reinhold, D., 1998, Observations of nocturnal foraging in the DoubleCrested Cormorant: Colonial Waterbirds, v. 21, p. 234-235.

Lang, T., Wosniok, W., Baršiene, J., Broeg, K., Kopecka, J., and Parkkonen, J., 2006, Liver histopathology in Baltic flounder (Platichthys flesus) as indicator of biological effects of contaminants: Marine Pollution Bulletin, v. 53, p. 488-496.

Lease, H.M., Hansen, J.A., Bergman, H.L., and Meyer, J.S., 2003, Structural changes in gills of Lost River sucker exposed to elevated $\mathrm{pH}$ and ammonia concentrations: Comparative Biochemistry and Physiology, v. 134, p. 491-500.

Loftus, M.E., 2001, Water quality stress to fish, in Effects of water quality and lake level on the biology and habitat of selected fish species in Upper Klamath Lake: Redmon, Washington, R2 Resource Consultants, Inc., $65 \mathrm{p}$.

Lom, J., and Dyková, I., 1992, Protozoan Parasites of Fish: Amsterdam, Elsevier Press.

Malbrouck, C., and Kestemont P., 2006, Effects of microcystins on fish: Environmental Toxicology and Chemistry, v. 25, p. 72-86.

Markle, D.F., and Clauson, K., 2006, Ontogenetic and habitat-related changes in diet of late larval and juvenile suckers (Catostomidae) in Upper Klamath Lake, Oregon: Western North American Naturalist, v. 66 , p. 492-501.

Markle, D.F., and Cooperman, M.S., 2002, Relationships between Lost River and shortnose sucker biology and management of Upper Klamath Lake, in Braunworth, W.S., Jr., Welch, T., and Hathaway, R., eds., Water allocation in the Klamath Reclamation Project, 2001: Corvallis, Oregon State University Extension Service, Special Report 1037, p. 93-117. [Also available at http://ir.library.oregonstate.edu/xmlui/bitstream/handle/1957/7132/SR percent20no. percent201037.pdf.]

McMahon, B.F., and Evans, R.M., 1992, Nocturnal foraging in the American White Pelican: The Condor, v. 94, p. 101-109.

Meyer, J.S., and Hansen, J.A., 2002, Subchronic toxicity of low dissolved oxygen concentrations, elevated $\mathrm{pH}$, and elevated ammonia concentrations to Lost River Suckers: Transactions of the American Fisheries Society, v. 131, p. 656-666.

Næsje, T.F., Forseth, T., Aursand, M., Saksgård, R., and Finstad, A.G., 2006, Lipid class content as an indicator of critical periods for survival in juvenile Atlantic salmon (Salmo salar): Ecology of Freshwater Fish, v. 15, p. 572-577.

National Research Council, 2004, Endangered and threatened fishes in the Klamath River Basin - Causes of decline and strategies for recovery: Washington, D.C., The National Academies Press, 397 p.

Nilsson, G., and Renshaw, G.M.C., 2004, Hypoxic survival strategies in two fishes-Extreme anoxia tolerance in the North European crucian carp and natural hypoxic preconditioning in a coral-reef shark: The Journal of Experimental Biology, v. 207, p. 3131-3139. 
Post, J.R., and Parkinson, E.A., 2001, Energy allocation strategy in young fish-Allometry and survival: Ecology, v. 82, p. 1040-1051.

Roze, T., Christen, F., Amerand, A., and Claireaux, G., 2013, Trade-off between thermal sensitivity, hypoxia tolerance and growth in fish: Journal of Thermal Biology, v. 38, p. 98-106.

Saiki, M.R., Monda, D.P., and Bellerud, B.L., 1999, Lethal levels of selected water quality variables to larval and juvenile Lost River and shortnose suckers: Environmental Pollution, v. 105, p. 37-44.

Scott, D.M., and Wilson, R.W., 2007, Three species of fishes from an eutrophic, seasonally alkaline lake are not more tolerant to acute exposure to high pH in the laboratory: Journal of Fish Biology, v. 70, p. 551566.

Smith, J.B., Grovenburg, T.W., Monteith, K.L., and Jenks, J.A., 2015, Survival of female bighorn sheep (Ovis Canadensis) in Black Hills, South Dakota: The American Midland Naturalist, v. 174, p. 290-301.

Terwilliger, M.R., Markle, D.F., and Kann, J., 2003, Associations between water quality and daily growth of juvenile shortnose and Lost River Suckers in Upper Klamath Lake, Oregon: Transactions of the American Fisheries Society, v. 132, p. 691-708.

Tranah, G.J., and May, B., 2006, Patterns of intra and interspecies genetic diversity in Klamath River Basin suckers: Transactions of the American Fisheries Society, v. 135, p. 306-316.

U.S. Environmental Protection Agency, 1979, Aqueous ammonia equilibrium-Tabulation of percent unionized ammonia: Duluth, Minnesota, EPA-600/3-79-091, 428 p.

U.S. Fish and Wildlife Service, 1988, Endangered and threatened wildlife and plants - Determination of endangered status for the shortnose sucker and Lost River sucker: Federal Register, v. 53, p. 27130 27134.

U.S. Fish and Wildlife Service, 2013, Revised recovery plan for the Lost River sucker (Deltistes luxatus) and shortnose sucker (Chasmistes brevirostris): U.S. Fish and Wildlife Service, Pacific Southwest Region, xviii +122 p.

U.S. Geological Survey, April 2004, Cleaning of equipment for water sampling (ver.2.0): U.S. Geological Survey Techniques of Water-Resources Investigations, book 9, chap. A3, accessed May 15, 2015, at http://pubs.water.usgs.gov/twri9A.

U.S. Geological Survey, 2006, Collection of water samples (ver. 2.0): U.S. Geological Survey Techniques of Water-Resources Investigations, book 9, chap. A4, accessed May 15, 2015, at http://pubs.water.usgs.gov/twri9A.

Weber, L.P., Higgins, P.S., Carlson, R.I., and Janz, D.M., 2003, Development and validation of methods for measuring multiple biochemical indices of condition in juvenile fishes: Journal of Fish Biology, v. 63, p. 637-658.

Welker, M.T., Pierce, C.L., and Wahl, D.H., 1994, Growth and survival of larval fishes_-Roles of competition and zooplankton abundance: Transactions of the American Fisheries Society, v. 123, p. 703717.

Wilkie, M.P., and Wood, C.M., 1996, The adaptations of fish to extremely alkaline environments: Comparative Biochemistry and Physiology, v. 113B, p. 665-637.

Williams, A.E., Moss, B., and Eaton, J., 2002, Fish induced macrophyte loss in shallow lakes-Top-down and bottom-up processes in mesocosm experiments: Freshwater Biology, v. 47, p. 2216-2232.

Zhou, B.S., Wu, R.S.S., Randall, D.J., Lam, P.K.S., Ip, Y.K., and Chew, S.F., 2000, Metabolic adjustments in the common carp during prolonged hypoxia: Journal of Fish Biology, v. 57, p. 1160-1171. 
Publishing support provided by the U.S. Geological Survey

Science Publishing Network, Tacoma Publishing Service Center

For more information concerning the research in this report, contact the Director, Western Fisheries Research Center U.S. Geological Survey

6505 NE 65th Street

Seattle, Washington 98115

http://wfrc.usgs.gov/ 
